\title{
Temperature and humidity dependence of secondary organic aerosol yield from the ozonolysis of $\beta$-pinene
}

\author{
C. von Hessberg ${ }^{1,2}$, P. von Hessberg ${ }^{2}$, U. Pöschl ${ }^{3}$, M. Bilde ${ }^{2}$, O. J. Nielsen ${ }^{2}$, and G. K. Moortgat ${ }^{1}$ \\ ${ }^{1}$ Atmospheric Chemistry Department, Max Planck Institute for Chemistry, J. J. Becherweg 29, 55128 Mainz, Germany \\ ${ }^{2}$ Copenhagen Center for Atmospheric Research, Department of Chemistry, University of Copenhagen, Universitetsparken 5, \\ 2100 Copenhagen $\varnothing$, Denmark \\ ${ }^{3}$ Biogeochemistry Department, Max Planck Institute for Chemistry, J. J. Becherweg 29, 55128 Mainz, Germany
}

Received: 15 January 2007 - Published in Atmos. Chem. Phys. Discuss.: 14 February 2007

Revised: 14 April 2009 - Accepted: 13 May 2009 - Published: 4 June 2009

\begin{abstract}
The temperature dependence of secondary organic aerosol (SOA) formation from ozonolysis of $\beta$-pinene was studied in a flow reactor at $263 \mathrm{~K}-303 \mathrm{~K}$ and $1007 \mathrm{hPa}$ under dry and humid conditions $(0 \%$ and $26 \%-68 \%$ relative humidity, respectively). The observed SOA yields reached maximum values of $0.18-0.39$ at high particle mass concentrations $\left(M_{o}\right)$. Under dry conditions, the measurement data showed an overall increase in SOA yield with inverse temperature, but significant oscillatory deviations from the predicted linear increase with inverse temperature (up to $50 \%$ at high $M_{o}$ ) was observed. Under humid conditions the SOA yield exhibited a linear decrease with inverse temperature. For the atmospherically relevant concentration level of $M_{o}=10 \mu \mathrm{g} \mathrm{m}^{-3}$ and temperature range $263 \mathrm{~K}-293 \mathrm{~K}$, the results from humid experiments in this study indicate that the SOA yield of $\beta$-pinene ozonolysis may be well represented by an average value of 0.15 with an uncertainty estimate of \pm 0.05 . When fitting the measurement data with a twoproduct model, both the partitioning coefficients $\left(K_{\text {om }, i}\right)$ and the stoichiometric yields $\left(\alpha_{i}\right)$ of the low-volatile and semivolatile model species were found to vary with temperature. The results indicate that not only the reaction product vapour pressures but also the relative contributions of different gasphase or multiphase reaction channels are strongly dependent on temperature and the presence of water vapour. In fact, the oscillatory positive temperature dependence observed under dry conditions and the negative temperature dependence observed under humid conditions indicate that the SOA yield is governed much more by the temperature and humidity dependence of the involved chemical reactions than by vapour
\end{abstract}

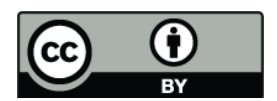

Correspondence to: C. von Hessberg (chste@mst.dk) pressure temperature dependencies. We suggest that the elucidation and modelling of SOA formation need to take into account the effects of temperature and humidity on the pathways and kinetics of the involved chemical reactions as well as on the gas-particle partitioning of the reaction products.

\section{Introduction}

Atmospheric aerosol particles affect the atmosphere and climate by absorption and scattering of radiation, by influencing the formation and properties of clouds and precipitation, and by heterogeneous chemical reactions (Pöschl, 2005; Fuzzi et al., 2006; McFiggans et al., 2006; Yu et al., 2006). In this study we investigate the formation of secondary organic aerosol (SOA) from ozonolysis of the biogenic volatile organic compound (BVOC) $\beta$-pinene, because $\beta$-pinene is very abundant and simulations have shown that SOA particles may be important as cloud condensation nuclei (Tunved et al., 2006). Forests and other vegetation emit large amounts of BVOC's (500-1800 Tg C $\left.a^{-1}\right)$, which are oxidised in the atmosphere primarily by $\mathrm{O}_{3}, \mathrm{OH}$ and $\mathrm{NO}_{3}$ radicals. Biogenic SOA are formed when low volatile oxidation products of BVOC condense on pre-existing or newly formed particles (Fry et al., 2009; Hallquist et al., 2009 and references therein).

Second to isoprene, monoterpenes are the most abundant BVOCs and they are usually assumed to account for most if not all SOA formation in current state-of-the-art models of global atmospheric chemistry (Kanakidou et al., 2005). With an emission rate of $10-50 \mathrm{Tg} \mathrm{C} \mathrm{a}{ }^{-1}, \beta$-pinene is the second most important monoterpene (Wiedinmyer et al., 2004), and several laboratory studies demonstrated the ability of

Published by Copernicus Publications on behalf of the European Geosciences Union. 
SOA from monoterpenes to act as cloud condensation nuclei (Hartz et al., 2005; VanReken et al., 2005; Engelhart et al., 2008; Asa-Awuku et al., 2009).

The temperature dependence of SOA formation from ozonolysis has been modelled by Sheehan and Bowman (2001), and their parameterization has been incorporated into some advanced global atmospheric chemistry models (Chung and Seinfeld, 2002; Tsigaridis and Kanakidou, 2003). Nevertheless, these models appear to underestimate the organic aerosol particle mass in the free troposphere, which may be due to shortcomings in the characterization and representation of the temperature dependence of SOA formation (Heald et al., 2005). To our knowledge only few experimental study has addressed this issue up to now: Takekawa et al. (2003) reported a twofold increase of the SOA yield from ozonolysis of $\alpha$-pinene at $283 \mathrm{~K} \mathrm{com-}$ pared to $303 \mathrm{~K}$, but they investigated no other temperatures or monoterpenes. Only very recently, the temperature dependence of SOA formation from ozonolysis of $\beta$-pinene (Pathak et al., 2008), $\alpha$-pinene and limonene (Pathak et al., 2007; Jonsson et al., 2008b; Saathoff et al., 2009) has been addressed experimentally. Burkholder et al. (2007) investigated particle nucleation following ozonolysis of $\alpha$ - and $\beta$ pinene over the temperature range $278-320 \mathrm{~K}$. In a model study Jenkin (2004) provided a highly detailed chemical description of SOA formation from $\alpha$ - and $\beta$-pinene ozonolysis including aerosol yields at three different temperatures. Svendby et al. (2008) has provided a temperature dependent parameterization of SOA yield using a two-product model.

Reactions (R1-R3) show steps in the gas phase ozonolysis of $\beta$-pinene: $\beta$-pinene

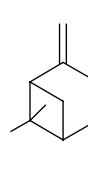

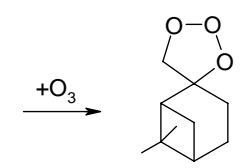

Primary ozonide
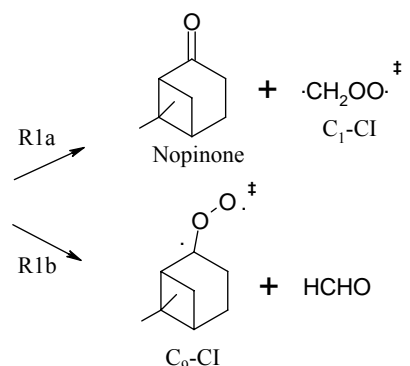

$\mathrm{C}_{9}-\mathrm{CI}$

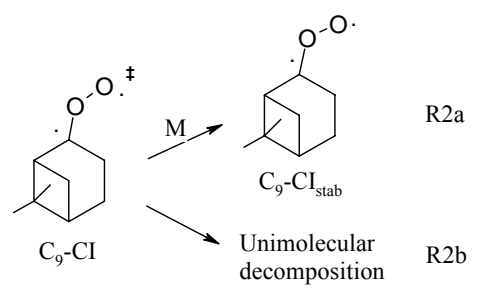

$\mathrm{R} 2 \mathrm{a}$

$\mathrm{R} 2 \mathrm{~b}$

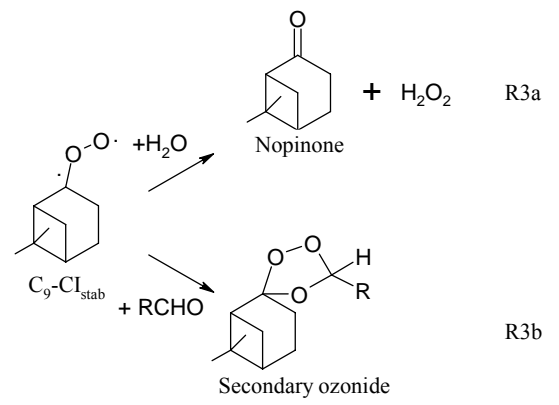

Water vapour has been found to reduce the particle volume concentration from ozonolysis of $\beta$-pinene (Bonn et al., 2002). The water vapour effect on SOA yield from other monoterpenes varies (Cocker et al., 2001; Jonsson et al., 2006, 2008b; Shilling et al., 2009). Jonsson et al. (2008a) have shown that the presence of an $\mathrm{OH}$ scavenger (and the type of the scavenger) can influence the water vapour dependence of the number and mass of particles from terpene ozonolysis. The decrease in particle volume concentration for $\beta$-pinene has been attributed to the reaction of water vapour (Reaction R3a) with the stabilized $\mathrm{C}_{9}-$ Criegee Intermediate $\left(\mathrm{C}_{9}-\mathrm{CI}_{\mathrm{stab}}\right)$ which increases the production of nopinone and hydrogenperoxide none of them condensing (Winterhalter et al., 2000). For comparison, recent studies have investigated ozonolysis of condensed phase alkenes (e.g. Chen et al., 2008; Vesna et al., 2008) and it has been suggested that humidity may affect ozonolysis products due to reaction of water molecules with Criegee intermediates on the particles (Vesna et al., 2008). Reaction (R3a) competes with the reaction of $\mathrm{C}_{9}-\mathrm{CI}_{\text {stab }}$ with carbonyl compounds (aldehydes or ketones) producing secondary ozonides (Reaction R3b), that may be important for new particle formation (Bonn et al., 2002).

For the elucidation, development, and evaluation of SOA formation mechanisms and model parameterizations we have experimentally investigated the temperature dependence of the SOA yield from the gas phase ozonolysis of $\beta$-pinene under both dry and humid conditions.

\section{Methods}

\subsection{Preparation of the reactants}

Ozone was generated by irradiation of a flow of synthetic air $\left(79.5 \% \mathrm{~N}_{2}\right.$ and $20.5 \% \mathrm{O}_{2}$, Air Liquide or Westfalen) mixed with nitrogen $\left(99.999 \% \mathrm{~N}_{2}\right.$, Air Liquide or Westfalen) with the UV light from a mercury Pen-Ray lamp. The volume mixing ratio of ozone was controlled by varying the ratio of synthetic air to nitrogen. The concentration of ozone was monitored by UV absorption at $\lambda=254 \mathrm{~nm}$ and calibrated with a commercial ozone monitor (Model 202, 2B Technologies, Inc.) mounted at the outlet of the flow reactor to account for wall loss of ozone. 
$\beta$-Pinene (99.5\%) was obtained from Sigma-Aldrich Chemical Co and used as received. It is a liquid with a vapour pressure of $313 \mathrm{~Pa}$ at $293 \mathrm{~K}$. The gas mix of $\beta$-pinene in nitrogen was prepared by evaporating pure $\beta$-pinene into an evacuated steel vessel $(V=14.671)$ and adding nitrogen to a pressure of about $6000 \mathrm{hPa}$. Experiments were performed two hours or more after the mixture was prepared. The concentration was measured with long-path FTIR spectroscopy. The concentration was determined from the area of two distinct peaks at ca. $3000 \mathrm{~cm}^{-1}$ and $1650 \mathrm{~cm}^{-1}$. The reference spectrum was calibrated by standard volumetric methods (Winterhalter et al., 2000). For each measurement 128 scans were made, and for each of the peaks nine measurements were performed alternating in groups of three measurements. The relative standard deviation of the measured values was less than $3 \%$. The concentration was obtained as the mean value of all measured values.

\subsection{Aerosol formation}

Figure 1 displays a schematic drawing of the experimental set-up applied in this study (described in detail by Bonn et al., 2002). The SOA formation experiments were performed in a vertical flow tube reactor $(120 \mathrm{~cm}$ length, $10 \mathrm{~cm}$ inner diameter, Pyrex glass walls), operated with a laminar gas flow of $51 \mathrm{~min}^{-1}$ and a center velocity of $2 \mathrm{~cm} \mathrm{~s}^{-1}$ (Bonn et al., 2002). All flows were controlled by MKS mass flow controllers. The temperature was taken into account when converting the volume flow to the mass flow of the flow controllers. The flow of ozone in synthetic air and nitrogen from the Pen-Ray lamp $\left(0.21 \mathrm{~min}^{-1}\right)$ was mixed with nitrogen to $2.01 \mathrm{~min}^{-1}$ and introduced through the center of the inlet mixing plunger. $\beta$-pinene from the pressurized steel vessel was mixed with synthetic air to a flow of $31 \mathrm{~min}^{-1}$ and introduced at the top of the flow reactor. For the experiments under humid conditions the synthetic air was humidified by passage over liquid water in a thermostatted vessel, before mixing with the $\beta$-pinene flow. The temperature of the vessel was adjusted in the range $293 \mathrm{~K}-323 \mathrm{~K}$ to establish $26 \%-68 \%$ relative humidity $(\mathrm{RH})$ in the flow reactor, which was measured by a dew-point meter (Panametrics, Moisture Monitor Series 35) at the excess flow outlet. To avoid damage of the dew-point meter, RH was only measured in the beginning and end of each experiment, when the air was free of particles. In the dry experiments test measurements showed that $\mathrm{RH}<0.03 \%$. The two flows containing ozone and $\beta$-pinene were mixed under turbulent conditions in the movable inlet mixing plunger. The reaction time $(\Delta t)$ was controlled by adjusting the distance between plunger and outlet. In the experiments reported here, the distance was kept at $80 \mathrm{~cm}$, to assure that the reactants reached the temperature of the flow reactor before being mixed, while having a maximized reaction time allowing minimal reactant concentrations. The amount of reacted $\beta$-pinene was varied by varying the initial volume mixing ratios of $\beta$-pinene and

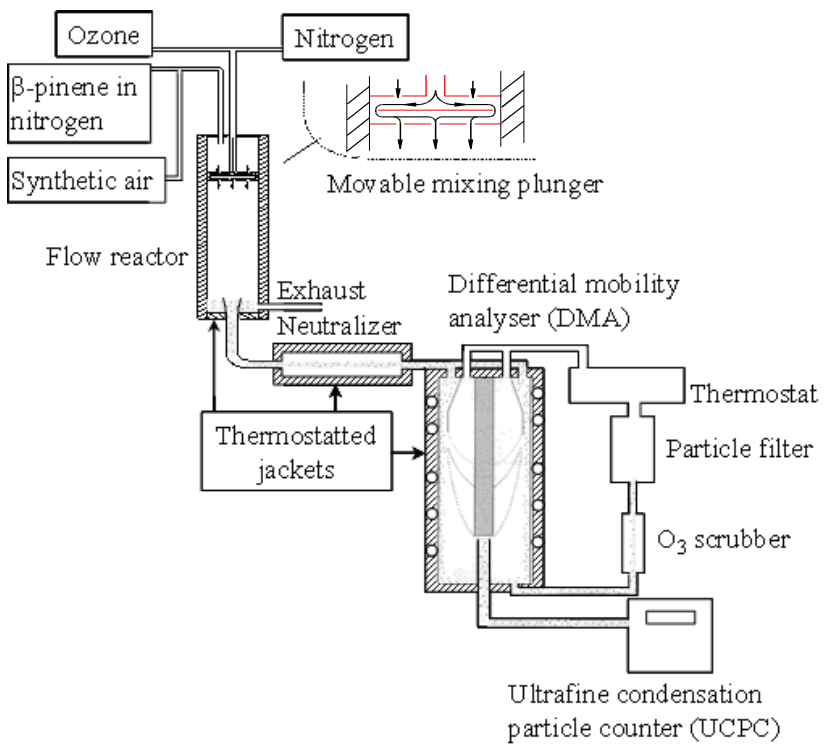

Fig. 1. Schematic drawing of the experimental set-up.

ozone over the range of $0.6 \mathrm{ppmv}-10.9 \mathrm{ppmv}$ and $0.2 \mathrm{ppmv-}$ 2.4 ppmv, respectively. The amount reacted was $0.4 \%-3.9 \%$ $\left(31 \mu \mathrm{g} \mathrm{m}^{-3}-1273 \mu \mathrm{g} \mathrm{m}^{-3}\right)$ for $\beta$-pinene and $0.5 \%-14.6 \%$ for ozone.

\subsection{Aerosol analysis}

Number size distributions of the particles formed in the flow reactor were measured with a scanning mobility particle sizer (SMPS) system (Model 3936, TSI Inc.) with a long differential mobility analyzer (LDMA, Model 3081, TSI Inc.) and ultrafine condensation particle counter (UCPC, Model 3025A, TSI Inc.). The sampling flow rate was $0.31 \mathrm{~min}^{-1}$, and the position of the sampling orifice with a radius of $1.1 \mathrm{~cm}$ was radially centered about $3 \mathrm{~cm}$ above the bottom of the flow reactor. Compared to the reaction time in the flow tube $(40 \mathrm{~s})$, the additional time in the neutralizer was negligible $(<1 \mathrm{~s})$. The DMA sheath air flow rate was varied between 3 and $9.71 \mathrm{~min}^{-1}$ (see Table 1) to optimize the relation between the detectable size range and the diffusional loss of the small particles. A few tests showed that the yield was not affected by the change in sheath air flow rate. The sheath air flow was regulated with a mass flow controller, and the temperature used for conversion of mass to volume flow rate was measured where the sheath air enters the DMA. To minimize ozonolysis inside the DMA, an ozone scrubber consisting of a glass tube filled with silver wool was installed in the sheath air loop, reducing the ozone concentration to less than the limit of detection ( 2 ppbv). Due to the ten-fold or higher dilution of the sample flow with ozone-free sheath air and short residence time (1.5 s), ozonolysis reactions in the DMA were negligible. The silver wool may also have scrubbed reaction products from the gas phase, but we assume that equilibrium 
Table 1. Conditions and results of individual dry experiments: $-\Delta[\beta$-pinene $]=$ decrease of $\beta$-pinene mass concentration, $N=$ total particle number concentration, $M_{o}=$ total particle mass concentration, $s_{M o}=$ standard deviation of $M_{O}, Y=$ SOA yield, $s_{Y}=$ standard deviation of $Y$, $n=$ number of measured number size distributions in each experiment, Sheath=sheath air flow in the DMA, reaction time $(\Delta t)=40 \mathrm{~s}$.

\begin{tabular}{|c|c|c|c|c|c|c|c|c|c|c|c|}
\hline & $T$ & {$[\beta \text {-pinene }]_{0}$} & {$[\text { ozone }]_{0}$} & $-\Delta[\beta$-pinene $]$ & $N$ & $M_{o}$ & $s_{M o}$ & $Y$ & $s_{Y}$ & $n$ & Sheath \\
\hline & $\mathrm{K}$ & ppbv & ppbv & $\mu \mathrm{g} \mathrm{m}^{-3}$ & $\# \mathrm{~cm}^{-3}$ & $\mu \mathrm{g} \mathrm{m}^{-3}$ & $\mu \mathrm{g} \mathrm{m}^{-3}$ & & & & $1 \min ^{-1}$ \\
\hline bp240106_6 & 263 & 601 & 1031 & 49.5 & $5.5 \mathrm{E}+05$ & 9.3 & 0.48 & 0.19 & 0.02 & 5 & 3.0 \\
\hline bp240106_5 & 263 & 601 & 1362 & 65.2 & $7.5 \mathrm{E}+05$ & 12.6 & 0.74 & 0.19 & 0.02 & 11 & 3.0 \\
\hline bp240106_4 & 263 & 754 & 1937 & 116.2 & $1.3 \mathrm{E}+06$ & 27.2 & 1.59 & 0.23 & 0.02 & 12 & 3.0 \\
\hline bp100106_3 & 263 & 2893 & 623 & 142.6 & $1.9 \mathrm{E}+06$ & 30.9 & 2.17 & 0.22 & 0.02 & 11 & 9.7 \\
\hline bp240106_3 & 263 & 3024 & 1934 & 462.6 & $3.3 \mathrm{E}+06$ & 123.9 & 5.80 & 0.27 & 0.02 & 5 & 3.0 \\
\hline bp240106_1 & 263 & 3031 & 1964 & 470.8 & $3.1 \mathrm{E}+06$ & 120.8 & 6.44 & 0.26 & 0.02 & 23 & 3.0 \\
\hline bp100106_2 & 263 & 5705 & 1126 & 501.7 & $3.4 \mathrm{E}+06$ & 121.0 & 8.27 & 0.24 & 0.02 & 15 & 9.7 \\
\hline bp240106_2 & 263 & 5977 & 1991 & 928.5 & $4.4 \mathrm{E}+06$ & 245.6 & 7.35 & 0.26 & 0.02 & 9 & 3.0 \\
\hline bp170106_3 & 273 & 754 & 669 & 44.9 & $3.4 \mathrm{E}+05$ & 10.1 & 0.56 & 0.23 & 0.02 & 13 & 9.7 \\
\hline bp170106_4 & 273 & 754 & 1190 & 79.6 & $9.7 \mathrm{E}+05$ & 23.8 & 1.74 & 0.30 & 0.03 & 13 & 6.0 \\
\hline bp040106_2 & 273 & 5991 & 376 & 194.6 & $2.5 \mathrm{E}+06$ & 60.6 & 3.11 & 0.31 & 0.02 & 9 & 9.7 \\
\hline bp170106_5 & 273 & 3151 & 1182 & 326.7 & $3.9 \mathrm{E}+06$ & 120.7 & 8.48 & 0.37 & 0.03 & 12 & 6.0 \\
\hline bp170106_2 & 273 & 6204 & 1188 & 635.8 & $4.2 \mathrm{E}+06$ & 241.3 & 7.81 & 0.38 & 0.03 & 11 & 9.7 \\
\hline bp220506_5 & 278 & 599 & 545 & 30.5 & $4.2 \mathrm{E}+05$ & 6.0 & 0.51 & 0.20 & 0.02 & 7 & 9.7 \\
\hline bp220506_2 & 278 & 783 & 721 & 52.7 & $7.5 \mathrm{E}+05$ & 10.6 & 1.13 & 0.20 & 0.02 & 22 & 9.7 \\
\hline bp220506_1 & 278 & 1375 & 1249 & 159.6 & $2.3 \mathrm{E}+06$ & 44.1 & 4.75 & 0.28 & 0.03 & 24 & 9.7 \\
\hline bp220506_4 & 278 & 2003 & 1815 & 336.9 & $4.1 \mathrm{E}+06$ & 114.6 & 11.90 & 0.34 & 0.04 & 15 & 9.7 \\
\hline bp220506_3 & 278 & 2782 & 2380 & 611.0 & $5.1 \mathrm{E}+06$ & 238.9 & 18.49 & 0.39 & 0.04 & 20 & 9.7 \\
\hline bp270106_1 & 283 & 1565 & 437 & 66.6 & $4.5 \mathrm{E}+05$ & 2.0 & 0.04 & 0.03 & 0.00 & 10 & 3.0 \\
\hline bp150306_1 & 283 & 1500 & 651 & 95.1 & $1.2 \mathrm{E}+06$ & 7.2 & 0.06 & 0.08 & 0.00 & 12 & 9.7 \\
\hline bp150306_2a & 283 & 1506 & 797 & 116.8 & $1.9 \mathrm{E}+06$ & 11.5 & 0.07 & 0.10 & 0.01 & 11 & 9.7 \\
\hline bp160306_1a & 283 & 1363 & 1266 & 168.2 & $2.7 \mathrm{E}+06$ & 25.2 & 0.29 & 0.15 & 0.01 & 17 & 9.7 \\
\hline bp270106_2 & 283 & 1565 & 1262 & 192.3 & $2.4 \mathrm{E}+06$ & 21.7 & 0.38 & 0.11 & 0.01 & 16 & 3.0 \\
\hline bp230106_6 & 283 & 1630 & 2086 & 329.9 & $3.6 \mathrm{E}+06$ & 52.7 & 0.70 & 0.16 & 0.01 & 12 & 3.0 \\
\hline bp230106_5 & 283 & 3253 & 2073 & 649.3 & $5.2 \mathrm{E}+06$ & 124.4 & 0.80 & 0.19 & 0.01 & 10 & 3.0 \\
\hline bp230106_1 & 283 & 6431 & 1233 & 748.8 & $4.8 \mathrm{E}+06$ & 124.6 & 1.38 & 0.17 & 0.01 & 13 & 9.7 \\
\hline bp230106_3 & 283 & 6430 & 1254 & 761.5 & $5.5 \mathrm{E}+06$ & 143.7 & 1.56 & 0.19 & 0.01 & 8 & 3.0 \\
\hline bp230106_2 & 283 & 6432 & 1288 & 782.3 & $5.1 \mathrm{E}+06$ & 147.8 & 2.01 & 0.19 & 0.01 & 11 & 9.7 \\
\hline bp230106_4 & 283 & 6430 & 2097 & 1273.1 & $6.6 \mathrm{E}+06$ & 280.1 & 1.76 & 0.22 & 0.01 & 9 & 3.0 \\
\hline bp140106_3 & 293 & 774 & 1280 & 105.3 & $2.2 \mathrm{E}+06$ & 15.9 & 0.54 & 0.15 & 0.01 & 4 & 9.7 \\
\hline bp191205_4 & 293 & 5444 & 199 & 111.9 & $2.4 \mathrm{E}+06$ & 20.5 & 0.26 & 0.18 & 0.01 & 10 & 5.0 \\
\hline bp130106_1 & 293 & 1611 & 658 & 112.4 & $2.6 \mathrm{E}+06$ & 23.6 & 0.17 & 0.21 & 0.01 & 11 & 9.7 \\
\hline bp140106_1 & 293 & 1611 & 1255 & 214.4 & $3.7 \mathrm{E}+06$ & 56.9 & 0.79 & 0.27 & 0.02 & 10 & 9.7 \\
\hline bp191205_1 & 293 & 5443 & 415 & 233.1 & $3.5 \mathrm{E}+06$ & 53.8 & 0.78 & 0.23 & 0.01 & 10 & 5.0 \\
\hline bp191205_2 & 293 & 5453 & 793 & 446.1 & $4.7 \mathrm{E}+06$ & 131.3 & 1.65 & 0.29 & 0.02 & 10 & 5.0 \\
\hline bp140106_2 & 293 & 6364 & 1269 & 828.4 & $5.8 \mathrm{E}+06$ & 283.6 & 3.23 & 0.34 & 0.02 & 4 & 9.7 \\
\hline bp191205_3 & 293 & 10863 & 790 & 853.2 & $5.7 \mathrm{E}+06$ & 274.9 & 3.45 & 0.32 & 0.02 & 8 & 5.0 \\
\hline bp210306_2 & 303 & 851 & 1309 & 128.0 & $1.1 \mathrm{E}+06$ & 7.4 & 0.16 & 0.06 & 0.00 & 17 & 9.7 \\
\hline bp201205_2 & 303 & 6682 & 215 & 158.0 & $1.6 \mathrm{E}+06$ & 15.9 & 0.50 & 0.10 & 0.01 & 8 & 9.7 \\
\hline bp210306_1 & 303 & 1361 & 1261 & 197.1 & $2.7 \mathrm{E}+06$ & 37.0 & 0.82 & 0.19 & 0.01 & 16 & 9.7 \\
\hline bp201205_3 & 303 & 6671 & 431 & 316.8 & $3.4 \mathrm{E}+06$ & 64.0 & 0.82 & 0.20 & 0.01 & 22 & 9.7 \\
\hline bp201205_1 & 303 & 6677 & 846 & 622.2 & $4.3 \mathrm{E}+06$ & 135.3 & 2.54 & 0.22 & 0.01 & 8 & 9.7 \\
\hline bp201205_4 & 303 & 10014 & 842 & 905.9 & $5.0 \mathrm{E}+06$ & 205.2 & 4.21 & 0.23 & 0.01 & 10 & 9.7 \\
\hline
\end{tabular}


Table 2. Conditions and results of individual humid experiments: $-\Delta[\beta$-pinene $]=$ decrease of $\beta$-pinene mass concentration, $N=$ total particle number concentration, $M_{o \text {, humid }}=$ total particle mass concentration not corrected for hygroscopic growth, $s_{M o}$, humid $=$ standard deviation of $M_{o \text {, humid }}, Y=$ SOA yield corrected for hygroscopic growth, $s_{Y}=$ standard deviation of $Y, n=$ number of measured number size distributions in each experiment, $\mathrm{RH}=$ relative humidity, $G F=$ growth factor, sheath air flow in the DMA=9.7 $1 \mathrm{~min}^{-1}$, reaction time $(\Delta t)=40 \mathrm{~s}$.

\begin{tabular}{|c|c|c|c|c|c|c|c|c|c|c|c|c|}
\hline & $T$ & {$[\beta \text {-pinene }]_{0}$} & {$[\text { ozone }]_{0}$} & $-\Delta[\beta$-pinene $]$ & $N$ & $M_{o, \text { humid }}$ & $s_{M o, \text { humid }}$ & $Y$ & $s_{Y}$ & $n$ & $\mathrm{RH}$ & $G F$ \\
\hline 020606_3 & 263 & 669 & 614 & 32.9 & $1.6 \mathrm{E}+05$ & 3.5 & 0.18 & 0.10 & 0.009 & 13 & 34 & 1.01 \\
\hline 020606_2 & 263 & 966 & 900 & 69.4 & $4.5 \mathrm{E}+05$ & 9.9 & 0.44 & 0.14 & 0.010 & 17 & 43 & 1.01 \\
\hline 020606_1 & 263 & 1997 & 1747 & 277.4 & $1.8 \mathrm{E}+06$ & 49.3 & 1.77 & 0.17 & 0.013 & 12 & 37 & 1.01 \\
\hline 020606_4 & 263 & 3760 & 3022 & 895.9 & $3.5 \mathrm{E}+06$ & 164.2 & 5.26 & 0.18 & 0.012 & 13 & 34 & 1.01 \\
\hline 240506_1 & 273 & 1460 & 1249 & 161.5 & $4.6 \mathrm{E}+05$ & 26.8 & 2.13 & 0.16 & 0.042 & 13 & 35 & 1.01 \\
\hline 240506_2 & 273 & 2116 & 1734 & 323.8 & $2.0 \mathrm{E}+06$ & 85.9 & 3.39 & 0.25 & 0.063 & 18 & 46 & 1.02 \\
\hline 070606_2 & 273 & 2571 & 2583 & 584.7 & $1.9 \mathrm{E}+06$ & 145.6 & 2.72 & 0.24 & 0.016 & 9 & 28 & 1.01 \\
\hline 060606_2 & 283 & 1363 & 1266 & 168.2 & $1.8 \mathrm{E}+06$ & 52.3 & 3.53 & 0.29 & 0.027 & 13 & 50 & 1.02 \\
\hline 060606_1 & 283 & 2550 & 2654 & 654.6 & $3.0 \mathrm{E}+06$ & 257.8 & 14.54 & 0.37 & 0.031 & 22 & 57 & 1.02 \\
\hline 230506_3 & 293 & 2114 & 1835 & 409.9 & $2.8 \mathrm{E}+06$ & 176.8 & 3.84 & 0.40 & 0.095 & 10 & 63 & 1.03 \\
\hline
\end{tabular}

was re-established when the sheath air was flowing through the filter collecting the SOA particles. For the humid experiments the sheath air was pre-conditioned for a couple of hours to ensure stable conditions throughout the system.

For each experiment the flow reactor and the SMPS system were kept at a common temperature (within $\pm 2 \mathrm{~K}$ ), by circulating ethanol/water through glass/steel jackets and through a hose wrapped around the DMA as illustrated in Fig. 1. A Julabo F20 cryostat combined with a Julabo FT 401 cooler was used for the flow reactor and the aerosol neutraliser, and a MGW Lauda RM6 cryostat for the DMA and its sheath air loop. Note that warm and humid conditions in the laboratory can lead to water condensation and short circuiting of the cooled DMA, which can be avoided by using only low voltages of the DMA.

In every SOA formation experiment, the number size distribution measurements were repeated 4-24 times. Conditions and results of the individual experiments are summarized in Table 1 for the dry experiments and Table 2 for the humid experiments.

\subsection{Data analysis}

SOA formation yields $(Y)$ were calculated as the ratio of the mass concentration of secondary organic particulate matter $\left(M_{o}\right)$ to the decrease of $\beta$-pinene mass concentration $(-\Delta[\beta-$ pinene]):

$Y=\frac{M_{o}}{-\Delta[\beta-\text { pinene }]}$
$M_{o}$ was calculated from the average of the measured mobility equivalent aerosol number size distributions, assuming compact spherical particles with an effective density of $1.2 \mathrm{~g} \mathrm{~cm}^{-3}$ (Bahreini et al., 2005). $M_{o}$ obtained under humid conditions ( $M_{o \text {,humid }}$ ) was corrected as follows to exclude the influence of water vapour uptake on particle size:

$$
\begin{aligned}
& M_{o}=\frac{M_{o, \text { humid }}}{G F^{3}} \\
& G F=\frac{D_{p, \text { wet }}}{D_{p, \text { dry }}}
\end{aligned}
$$

$G F$ is the growth factor and $D_{p}$ is the particle diameter. Varutbangkul et al. (2006) have reported the dependency of $G F$ on relative humidity (RH) for SOA particles from $\beta$ pinene ozonolysis in the presence of seed aerosol in a chamber setting:

$G F=1+\left[\left(1-\frac{\mathrm{RH}}{100 \%}\right)\right]^{-0.5108} \times 0.0367\left(\frac{\mathrm{RH}}{100 \%}\right)^{1.5177}$

We assume that the hygroscopicity and growth factor $(G F)$ did not significantly vary with temperature, particle age, the use of seed aerosols and related changes of SOA yield and composition. Although the experimental conditions used by Varutbangkul et al. (2006) were different from the conditions applied in this study the results were taken as the best available approximation of $G F$ for SOA particles from $\beta$-pinene 
ozonolysis. Since the corrections for hygroscopic growth under our experimental conditions were relatively minor (5\%$11 \% \mathrm{v} / \mathrm{v}$ ), influence of potential errors of $G F$ appear negligible.

For the determination of $-\Delta[\beta$-pinene $]$ we calculated the decrease of ozone concentration $\left(-\Delta\left[\mathrm{O}_{3}\right]\right)$ assuming pseudo-first order reaction kinetics based on a near-constant excess concentration of $([\beta$-pinene $])([\beta$-pinene $]$ :

$$
\begin{aligned}
& -\Delta\left[\mathrm{O}_{3}\right]=\left[\mathrm{O}_{3}\right]_{0} \times\left(1-\exp \left(k_{\mathrm{O}_{3}}[\beta-\text { pinene }]_{0} \Delta t\right)\right) \\
& -\Delta[\beta-\text { pinene }]=1.35\left(-\Delta\left[\mathrm{O}_{3}\right]\right)
\end{aligned}
$$

The factor of 1.35 was applied, because the ozonolysis of $\beta$-pinene produces $\mathrm{OH}$ radicals with a stoichiometric yield $\left(\alpha_{\mathrm{OH}}\right)$ of 0.35 at $296 \mathrm{~K}$ (Atkinson et al., 1992). We assumed that $\alpha_{\mathrm{OH}}$ was independent of temperature (R. Atkinson, personal communication, 2006), that $\mathrm{OH}$ was in steady state $\left(k_{\mathrm{OH}}=7.89 \times 10^{-11} \mathrm{~cm}^{3}\right.$ molecule ${ }^{-1} \mathrm{~s}^{-1} \gg k_{\mathrm{O}_{3}}=1.5 \times 10^{-17}$

$\mathrm{cm}^{3}$ molecule $\mathrm{s}^{-1}$ at $298 \mathrm{~K}$, Atkinson, 1994) and that all $\mathrm{OH}$ radicals reacted with $\beta$-pinene, which is supported by the large excess of $\beta$-pinene compared to its reaction products $\left(-\Delta[\beta\right.$-pinene $\left.] /[\beta \text {-pinene }]_{0}<4 \%\right)$, even for experiments with excess ozone. For the few experiments where $\left[\mathrm{O}_{3}\right]_{0}$ was higher than $[\beta \text {-pinene }]_{0},-\Delta[\beta$-pinene $]$ was calculated from Eq. (5) interchanging $\beta$-pinene and ozone. Temperature-dependent reaction rate coefficients $\left(k_{\mathrm{O}_{3}}\right)$ were calculated from the Arrhenius equation:

$k_{\mathrm{O}_{3}}=A \exp \left(\frac{-E_{a}}{R T}\right)$

where $\quad A=1.2 \times 10^{-15} \pm 4.6 \times 10^{-17} \mathrm{~cm}^{3}$ molecule ${ }^{-1} \mathrm{~s}^{-1}$, $E_{a} / R=1300 \pm 75 \mathrm{~K}$ (Khamaganov and Hites, 2001; Atkinson and Arey, 2003).

Standard deviations of $M_{o}\left(s_{M o}\right)$ were calculated from repeated measurements of the SOA number size distribution. The number of measured size distributions $(n)$ in each experiment is given in Tables 1 and 2. The standard deviation of the yield $\left(s_{Y}\right)$ was calculated by propagating $s_{M o}$ and the standard deviation of $-\Delta[\beta$-pinene $]\left(s_{-\Delta \beta-\text { pinene }}\right)$ :

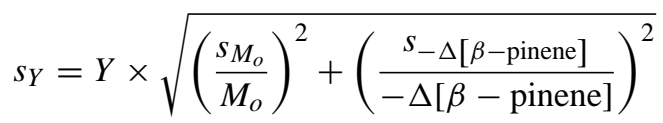

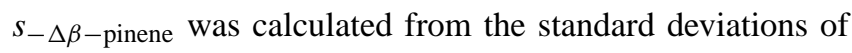
$\alpha_{\mathrm{OH}},\left[\mathrm{O}_{3}\right]_{0},[\beta \text {-pinene }]_{0}, \Delta t$ and $k_{\mathrm{O}_{3}}$ :

$s_{-\Delta[\beta-\text { pinene }]}=(-\Delta[\beta-$ pinene $]) \times$

$$
\sqrt{\left(\frac{s_{\alpha_{\mathrm{OH}}}}{\alpha_{\mathrm{OH}}}\right)^{2}+\left(\frac{s_{\left[\mathrm{O}_{3}\right]_{0}}}{\left[\mathrm{O}_{3}\right]_{0}}\right)^{2}+\left(\frac{s_{k_{\mathrm{O}_{3}}}}{k_{\mathrm{O}_{3}}}\right)^{2}+\left(\frac{s_{\Delta t}}{\Delta t}\right)^{2}+\left(\frac{s_{[\beta-\text { pinene }]_{0}}}{[\beta-\text { pinene }]_{0}}\right)^{2}}
$$

\subsection{Two-product model}

The ozonolysis of $\beta$-pinene generates a large variety of reaction products (Winterhalter et al., 2000). Commonly the products of this and other SOA formation reactions are lumped into low-volatile and semi-volatile species, and a two-product model is used to simulate the SOA yield from smog chamber data (Odum et al., 1996):

$Y=M_{o}\left(\frac{\alpha_{1} K_{o m, 1}}{R_{s, 1}+K_{o m, 1} M_{o}}+\frac{\alpha_{2} K_{o m, 2}}{R_{s, 2}+K_{o m, 2} M_{o}}\right)$

$K_{o m, i}$ stands for the gas-particle partitioning coefficients, $\alpha_{i}$ is the stoichiometric yield and $R_{s, i}$ is the mass fraction of particulate matter that remains suspended in the gas. The counting variable $i$ designates low volatile species (1) and semi-volatile species (2), respectively. During the short residence time in the flow reactor, the sampled aerosol does practically not interact with the walls, and thus we assume $R_{S, i}=1$. For any wall loss to occur the particles in the sample flow would have to migrate by Brownian diffusion over a distance of $3.9 \mathrm{~cm}$ from the radially centered sampling orifice to the walls. For the smallest detected particles with a diameter of $8 \mathrm{~nm}$, the probability for displacement larger than $0.4 \mathrm{~cm}$ within $40 \mathrm{~s}$ is only $0.3 \%$. In contrast, the particle residence times in smog chamber experiments are typically in the order of hours, which leads to significant wall losses and $R_{s, i}<1$.

\subsection{Fitting procedures}

\subsection{1 "B fit"}

Non-linear robust fits (Huber, 1981) of Eq. (10) to the experimental data pairs of $M_{o}$ and $Y$ were performed. The input parameters $K_{o m, 1,303 \mathrm{~K}}$ and $K_{o m, 2,303 \mathrm{~K}}$ were varied from $0.001 \mathrm{~m}^{3} \mu \mathrm{g}^{-1}$ to $0.2 \mathrm{~m}^{3} \mu \mathrm{g}^{-1}$ in steps of $0.001 \mathrm{~m}^{3} \mu \mathrm{g}^{-1}$ with the premise that $K_{o m, 1,303 \mathrm{~K}}>K_{o m}, 2,303 \mathrm{~K}$. The temperature dependence of $K_{o m, i}$ was derived from the ClausiusClayperon equation describing the temperature dependence of the vapour pressure (Sheehan and Bowman, 2001):

$$
\begin{aligned}
& K_{\text {om }, i, T}=K_{\text {om }, i, 303 \mathrm{~K}} \frac{T}{303 \mathrm{~K}} \exp \left[B_{i}\left(\frac{1}{T}-\frac{1}{303 \mathrm{~K}}\right)\right] \\
& B_{i}=\frac{\Delta_{\mathrm{vap}} H_{i}}{R} \approx \frac{\Delta_{\mathrm{vap}} S_{i} \times T_{b, i}}{R}
\end{aligned}
$$

Pinalic-3-acid and pinic acid were chosen as representatives for the low volatile species (1) and nopinone was chosen to represent the semi-volatile species (2). B values for the three species were calculated with the values of $\Delta_{\mathrm{vap}} S_{i}$ and $T_{b, i}$ reported by Jenkin (2004). The two acids were lumped using the method of Bian and Bowman (2002) with $\alpha$ and $\mathrm{K}$ values from Jenkin (2004). This led to $B_{1}=6153 \mathrm{~K}$ and $B_{2}=5032 \mathrm{~K}$. Start values of $\alpha_{1}$ and $\alpha_{2}$ (Table 3 ) were determined by test calculations, and for each temperature $\alpha_{1}$ and $\alpha_{2}$ were optimized with a Nelder-Mead algorithm (Nelder and Mead, $1965)$ to minimize the residual parameter $S_{T}$ :

$$
S_{T}=\sum_{i} \frac{\left|Y_{\text {data }, T}-Y_{\text {model }, T}\right|_{i}}{s_{Y, \text { data }, T, i}}
$$

Best fit values of $K_{o m, 1,303 \mathrm{~K}}$ and $K_{o m, 2,303 \mathrm{~K}}$ were taken at the minimum of the sum of residual parameters $\Sigma S_{T}$. 
Table 3. Start values for the two-product model fit to the measurement data from dry and humid experiments: $\alpha_{1}$ and $\alpha_{2}$ are the stoichiometric yields of the low volatile and semi volatile species.

\begin{tabular}{lcccc}
\hline & \multicolumn{2}{c}{ dry } & \multicolumn{2}{c}{ humid } \\
\hline$T(\mathrm{~K})$ & $\alpha_{1}$ & $\alpha_{2}$ & $\alpha_{1}$ & $\alpha_{2}$ \\
\hline 263 & 0.10 & 0.17 & 0.15 & 0.04 \\
273 & 0.09 & 0.29 & 0.25 & 0.04 \\
278 & 0.10 & 0.30 & & \\
283 & 0.03 & 0.18 & 0.26 & 0.13 \\
293 & 0.01 & 0.33 & 0.40 & 0.04 \\
303 & 0.08 & 0.16 & & \\
\hline
\end{tabular}

\subsection{2 "Free fit"}

To investigate how the fit values change without constraints on the temperature dependence the data sets obtained at different temperatures have been fitted independently by varying the input parameters $K_{o m, 1}$ and $K_{o m, 2}$ from $0.001 \mathrm{~m}^{3} \mu \mathrm{g}^{-1}$ to $0.8 \mathrm{~m}^{3} \mu \mathrm{g}^{-1}$ with steps of $0.001 \mathrm{~m}^{3} \mu \mathrm{g}^{-1}$. For the data from experiments at $263 \mathrm{~K}$ (dry and humid) and $278 \mathrm{~K}$ (dry) it was necessary to raise the upper limit to $100000 \mathrm{~m}^{3} \mu \mathrm{g}^{-1}$ (steps of $10 \mathrm{~m}^{3} \mu \mathrm{g}^{-1}$ ), $300 \mathrm{~m}^{3} \mu \mathrm{g}^{-1}$ (steps of $1 \mathrm{~m}^{3} \mu \mathrm{g}^{-1}$ ) and $3.150 \mathrm{~m}^{3} \mu \mathrm{g}^{-1}$ (steps of $0.001 \mathrm{~m}^{3} \mu \mathrm{g}^{-1}$ ), respectively. Start values of $\alpha_{1}$ and $\alpha_{2}$ were identical to those used for the "B-fit" (Table 3). For both the "B-fit" and the "free-fit" the $\alpha_{i}$ best-fit values were not correlated with the start values, confirming that fitting results were not biased by the start values.

\subsection{Earlier investigations}

\subsubsection{Experimental studies}

Six experimental studies on the aerosol yield of $\beta$-pinene ozonolysis have to our knowledge been published. They have been conducted in static smog chambers under different experimental conditions. Five of them are summarised in Table 4, but none of them covered a temperature and humidity range wider than a few $\mathrm{K}$ and few $\% \mathrm{RH}$, respectively. The sixth study (Pathak et al., 2008) was published during the course of this work. It covered the temperature range from 273-313 K and will be discussed separately.

Most of the previous studies used seed aerosols, which are assumed to affect measurements of SOA yield only at very low particle number and mass concentrations (kinetic limitations of particle nucleation and growth). The lowest particle number and mass concentrations measured in our experiments were $3.4 \times 10^{5} \mathrm{~cm}^{-3}$ and $1.9 \mu \mathrm{g} \mathrm{m}^{-3}$, which should be sufficiently high to avoid kinetic limitations and ensure comparability with earlier studies using seed aerosols.
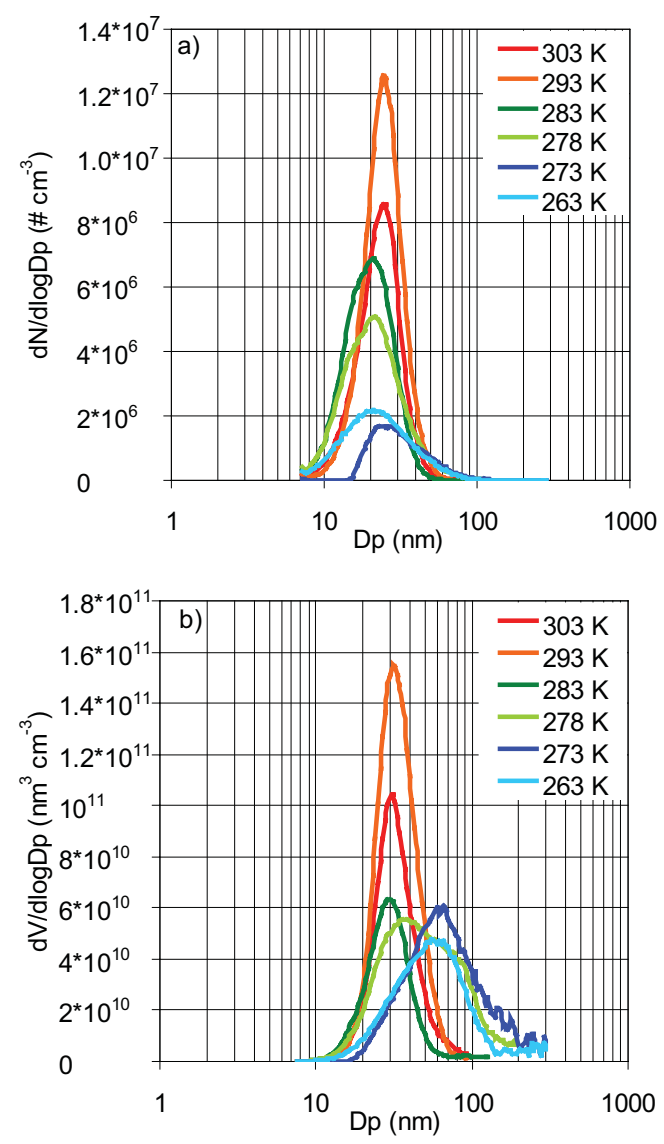

Fig. 2. Average (arithmetic mean of 6-24 scans) particle number (a) and volume (b) size distributions from dry experiments with $[\beta \text {-pinene }]_{0}=1.28 \mathrm{ppmv}-1.38 \mathrm{ppmv}$ (except for $293 \mathrm{~K}$ : $[\beta$ pinene $]_{0}=1.61 \mathrm{ppmv}$ ) and $\left[\mathrm{O}_{3}\right]_{0} \approx 1.25 \mathrm{ppmv}$ at different temperatures $(263 \mathrm{~K}-303 \mathrm{~K})$.

No OH scavenger was applied in this study. This might complicate comparison to other experimental results from studies using $\mathrm{OH}$ scavengers since the influence of scavenger on the aerosol yield depend on the type of alkene and $\mathrm{OH}$ scavenger (Docherty and Ziemann, 2003; Keywood et al., 2004). Griffin et al. (1999) and Yu et al. (1999) applied 2butanol as an $\mathrm{OH}$ scavenger, which has been found to reduce the SOA yield from $\beta$-pinene ozonolysis substantially (Keywood et al., 2004). Lee et al. (2006) applied cyclohexane for $\mathrm{OH}$ scavenging, which has been found not to affect the SOA yield from $\beta$-pinene ozonolysis significantly (Docherty and Ziemann, 2003). Jaoui and Kamens (2003) used rural background air containing natural $\mathrm{OH}$ scavengers.

Most of the earlier studies assumed a particle density of $1 \mathrm{~g} \mathrm{~cm}^{-3}$, only Lee et al. (2006) assume $1.25 \mathrm{~g} \mathrm{~cm}^{-3}$. We assume a particle density of $1.2 \mathrm{~g} \mathrm{~cm}^{-3}$ based on Bahreini et al. (2005). Two of the previous studies reported fitparameters for a one- or two-product model of SOA formation (Hoffmann et al., 1997; Griffin et al., 1999). 
Table 4. Experimental conditions for studies regarding yield from $\beta$-pinene ozonolysis.

\begin{tabular}{lllll}
\hline & $T(\mathrm{~K})$ & Seed aerosol & RH (\%) & OH scavenger \\
\hline Hoffmann et al. (1997) & 292 & + & - & - \\
Griffin et al. (1999) & $307-308$ & + & 5 & 2-butanol \\
Yu et al. (1999) & $306-308$ & + & - & 2-butanol \\
Jaoui and Kamens (2003) & $285-290$ & - & $40-50$ & - \\
Lee et al. (2006) & 293 & + & 6.3 & cyclohexane \\
This study & $263-303$ & - & $<0.03 ; 26-68$ & - \\
\hline
\end{tabular}

\subsubsection{Model studies}

In a number of models developed to predict SOA yields, a wide variety of gas-phase reaction products are lumped on the basis of their vapour pressures, and representative $\alpha_{i}, K_{o m, i}$ and $B_{i}$ values are calculated for each lumped species (Cocker et al., 2001; Kamens and Jaoui, 2001; Bian and Bowman, 2002). The stoichiometric yields $\alpha_{i}$ are usually assumed to be independent of temperature, whereas the gas-particle partitioning coefficients $K_{o m, i}$ are assumed to have a Clausius-Clapeyron-type temperature dependence (Sect. 2.6), implying proportionality between SOA yield and inverse temperature.

Svendby et al. (2008) have fitted the two-product model to the data of Griffin et al. (1999) and Yu et al. (1999) and presented the temperature dependence of the parameters $\alpha_{i}$, $K_{\text {om }, i}$.

Jenkin (2004) has presented a comprehensive modeling study of SOA formation from $\beta$-pinene ozonolysis: gas phase chemistry is described using the Master Chemical Mechanism (version 3), coupled with a representation of gas-to-aerosol transfer of ca. 200 semivolatile and involatile oxygenated products. Jenkin (2004) illustrates the dependence of the simulated yield of aerosol mass versus mass of organic aerosol for three temperatures. He assumed a particle density of $1 \mathrm{~g} \mathrm{~cm}^{-3}$, which is expected to lower the yield compared to our assumption of $1.2 \mathrm{~g} \mathrm{~cm}^{-3}$. Also the simulation contains enough water vapour to scavenge stabilised Criegee intermediates. Even though our experimental reaction conditions are not identical to those assumed by Jenkin (2004) we choose to compare to Jenkin's results, since it is the most comprehensive theoretical study of $\beta$-pinene ozonolysis available.

\section{Results and discussion}

SOA formation experiments have been performed at six different temperatures in the range of $263 \mathrm{~K}-303 \mathrm{~K}$ under dry and humid conditions and SOA yields have been determined from the measured number size distributions and calculated amounts of reacted $\beta$-pinene as detailed in Sect. 2. The conditions and results of the individual experiments are listed in Tables 1 and 2.

\subsection{Particle concentrations and size distributions}

Figure 2 displays average (arithmetic mean) particle number and volume size distributions of dry experiments performed with about $1.25 \mathrm{ppmv}$ ozone and $1.28-1.37 \mathrm{ppmv} \beta$ pinene, except for the measurement at $293 \mathrm{~K}$ performed with $1.61 \mathrm{ppmv} \beta$-pinene. The number of scans conducted to obtain the average size distributions is shown in Table 1. The modal diameter of the number size distributions was fairly constant $(20 \mathrm{~nm}-30 \mathrm{~nm})$, and the integrated number concentrations exhibited a trend to decrease with decreasing temperature. In contrast, the modal diameter of the volume size distributions is $30 \mathrm{~nm}$ at $283 \mathrm{~K}-303 \mathrm{~K}$ but increases over $38 \mathrm{~nm}$ at $278 \mathrm{~K}$ to $60 \mathrm{~nm}$ at $263 \mathrm{~K}$ and $273 \mathrm{~K}$. The integrated volume concentrations exhibited an increasing trend with decreasing temperature (albeit oscillatory rather than monotonous, as discussed below).

Figure 3 displays average (arithmetic mean) particle number and volume size distributions of humid experiments $(26 \%-68 \% \mathrm{RH})$ with about $1.25 \mathrm{ppmv}$ ozone and $0.97-$ 1.76 ppmv $\beta$-pinene. The number of scans conducted to obtain the average size distributions is shown in Table 2. Under humid conditions, both the modal diameter of the number size distributions $(20 \mathrm{~nm}-40 \mathrm{~nm})$ and the integrated particle number concentrations decreased with decreasing temperature. The integrated volume concentration also exhibited a clear decrease with decreasing temperature, whereas the modal diameters of the volume size distributions increased $(40 \mathrm{~nm}-60 \mathrm{~nm})$. The $273 \mathrm{~K}$ volume size distribution shown in Fig. $3 b$ exhibits two modes of similar intensity (one at $\sim 50 \mathrm{~nm}$ and one at $\sim 90 \mathrm{~nm}$ ). This is not typical though; the average volume size distributions obtained at the other concentrations of ozone and $\beta$-pinene applied at $273 \mathrm{~K}$ (not shown) were monomodal. The reason for the occurrence of the second mode at $273 \mathrm{~K}$ is unclear; it should be noted that it does not substantially change the observed decrease of aerosol particle volume with decreasing temperature. The 

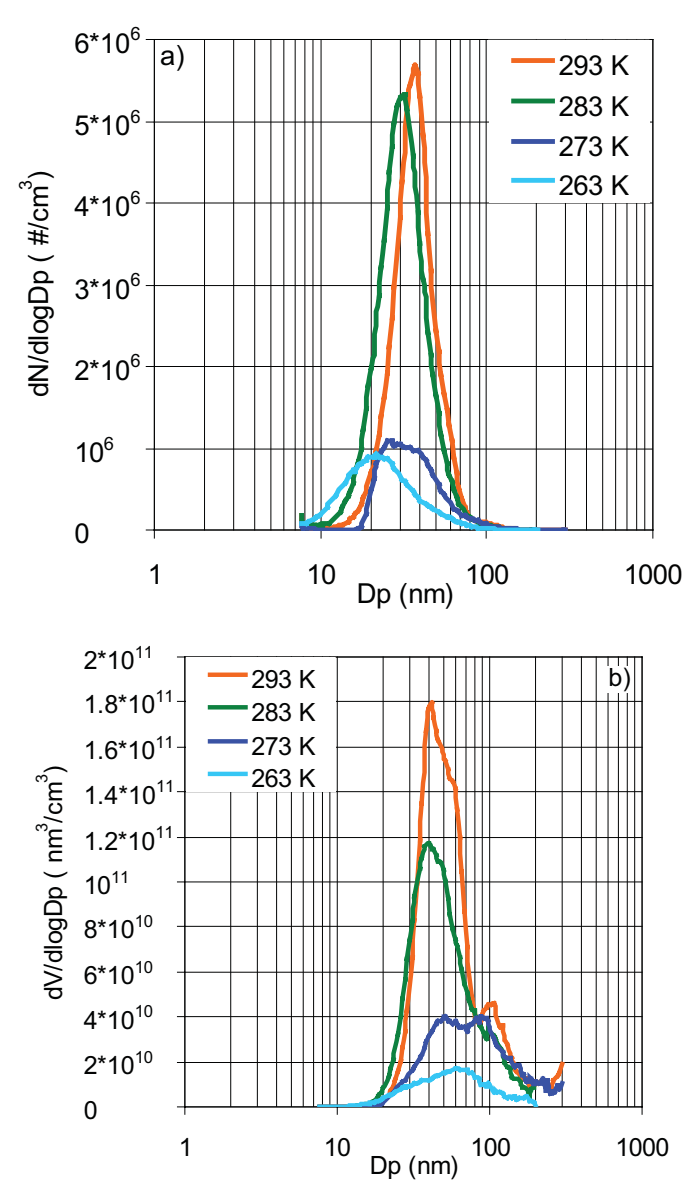

Fig. 3. Average (arithmetic mean of 13-23 scans) particle number (a) and volume (b) size distributions from humid experiments with $[\beta \text {-pinene }]_{0}=0.97 \mathrm{ppmv}-1.76 \mathrm{ppmv}$ and $\left[\mathrm{O}_{3}\right]_{0} \approx 1.25 \mathrm{ppmv}$ (except for $\left.263 \mathrm{~K}:\left[\mathrm{O}_{3}\right]_{0}=0.9 \mathrm{ppmv}\right)$ at different temperatures $(263 \mathrm{~K}-$ $293 \mathrm{~K})$.

$293 \mathrm{~K}$ volume size distribution shown in Fig. 3b displays a shoulder at $\sim 100 \mathrm{~nm}$. This was also observed for the average volume size distributions at two other concentrations at $293 \mathrm{~K}$ (five concentrations were studied in total). The reason for the occurrence of a shoulder is not known, but does not affect the observed decrease of aerosol particle volume with decreasing temperature.

Compared to the dry experiments, the particle number concentrations under humid conditions were generally lower, whereas the particle volume concentrations were higher at $283 \mathrm{~K}$ and $293 \mathrm{~K}$ and lower at $263 \mathrm{~K}$ and $273 \mathrm{~K}$.

Overall, the measured particle concentrations and size distributions indicate that the yield of nucleating species responsible for new particle formation decreased with decreasing temperature, both under dry and humid conditions. Under humid conditions also the yield of condensing species responsible for particle growth decreased with decreasing temperature. For all temperatures the addition of water vapour resulted in a reduction of the yield of nucleating species, whereas the yield of condensing species was reduced at low temperatures $(263 \mathrm{~K}$ and $273 \mathrm{~K}$ ) and increased at high temperatures ( $283 \mathrm{~K}$ and $293 \mathrm{~K}$ ).

Bonn et al. (2002) reported a decrease in particle number and volume upon addition of water vapour at $295 \mathrm{~K}$. Bonn et al. (2002) used cyclohexane as an $\mathrm{OH}$ scavenger, which has been shown to affect SOA yield (Jonsson et al., 2008a).

\subsection{Concentration dependence of SOA yield}

Figure 4 summarises the results of all dry experiments in a plot of SOA yield versus $M_{o}$. At all temperatures, the yield exhibits a steep near-linear increase with $M_{o}$ for $M_{o}<10 \mu \mathrm{g} \mathrm{m}^{-3}$ and reaches a near-constant maximum level for $M_{o}>100 \mu \mathrm{g} \mathrm{m}^{-3}$. This behaviour can be fitted with the two-product model outlined in Sect. 2.5 and 2.6; the parameters of the shown fit lines are summarized in Table 5 and will be discussed below.

The error bars depict the standard deviations for $M_{O}$ and SOA yield, calculated as described in Sect. 2.4. They illustrate that the relative standard deviations of repeated measurements within one experiment were mostly $10 \%$ or less. The standard deviations between the mean values of SOA yield obtained in different experiments repeated under nearidentical conditions (similar $T$ and $\Delta[\beta$-pinene $]$ ) were generally $\leq 0.05$, corresponding to relative standard deviations up to $15 \%$.

The standard deviation of the ozonolysis reaction rate coefficient $k_{\mathrm{O}_{3}}\left(s_{\mathrm{O}_{3}}\right)$ was not included in the error bars of Fig. 4, i.e. $s_{\mathrm{O}_{3}}$ was excluded from their calculation through Eq. (9). $s_{\mathrm{O}_{3}}$ varies only little over the investigated temperature range and does not affect the statistical uncertainty of our experimental data. It should, however, be taken into account when comparing the results to other studies and extrapolating to the atmosphere. When $s_{\mathrm{O}_{3}}$ is included in Eq. (9), $s_{Y}$ is a factor of 2 to 3 larger than the error bars displayed in Fig. 4. The same applies to the SOA yields and uncertainties of the humid experiments presented below (Sect. 2.4, Fig. 5). Clearly, a reduction of the uncertainty of the ozonolysis rate coefficient is of central importance for reducing uncertainties of SOA formation and mass concentrations in atmospheric models. If future investigations were to reveal differences between the actual value of $k_{\mathrm{O}_{3}}$ and the value used here, the results of this study could be scaled accordingly.

As illustrated in Fig. 4, the maximum yield from the study by Hoffmann et al. (1997) at 292 K (open diamonds) agrees quite well with the maximum yield from our study at $293 \mathrm{~K}$ (filled diamonds). At $M_{o}<150 \mu \mathrm{g} \mathrm{m}^{-3}$, however, the yields of Hoffmann et al. (1997) were about $20 \%$ higher, even though they had assumed lower particle density (1.0 vs. $1.2 \mathrm{~g} \mathrm{~cm}^{-3}$, Sect. 2.7). A possible explanation for the differences is that Hoffmann et al. (1997) measured the denominator in the calculation of the SOA yield, $-\Delta[\beta-$ pinene], whereas it has been calculated in this study, subject to the large uncertainty of $k_{\mathrm{O}_{3}}$ outlined above. Hoffmann 

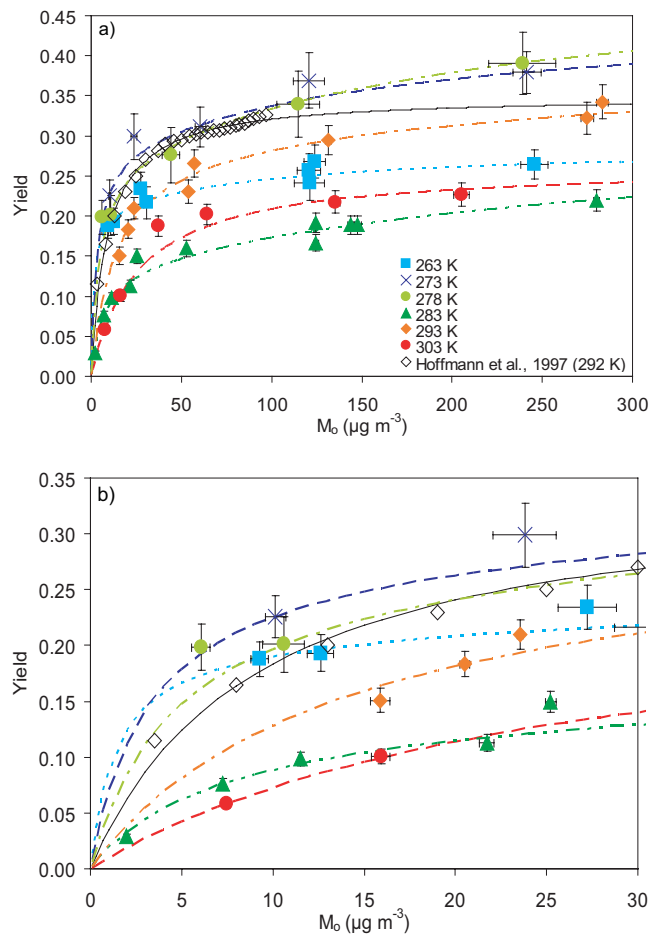

Fig. 4. Secondary organic aerosol yield $(Y)$ plotted against mass concentration of organic particulate matter $\left(M_{O}\right)$ from dry experiments performed at different temperatures $(263 \mathrm{~K}-303 \mathrm{~K})$ : (a) all data from this study (Table 1), and Hoffmann et al. (1997); (b) blow-up of low $M_{O}$ range from Fig. 4a. Symbols and error bars represent the arithmetic mean and standard deviations of 4-24 replicate measurements performed in each experiment. Lines represent two-product model "B fits" (Table 5).

et al. (1997) have only measured yields for $M_{o}$ up to ca. $100 \mu \mathrm{g} \mathrm{m}^{-3}$. In this range the ratio of the yields of Hoffmann et al. (1997) to our results is roughly 1.25 . At $293 \mathrm{~K}$ we used a $k_{\mathrm{O}_{3}}$-value of $1.4 \times 10^{-17} \mathrm{~cm}^{3}$ molecule ${ }^{-1} \mathrm{~s}^{-1}$; using a $k_{\mathrm{O}_{3}}$ of $1.1 \times 10^{-17} \mathrm{~cm}^{3}$ molecule ${ }^{-1} \mathrm{~s}^{-1}$ instead would make our yields agree with the results from Hoffmann et al. (1997). This value is within the uncertainty range of $k_{\mathrm{O}_{3}} \quad\left(1.06 \times 10^{-17}-1.90 \times 10^{-17} \mathrm{~cm}^{3}\right.$ molecule $\left.\mathrm{s}^{-1} \mathrm{~s}^{-1}\right)$ (Khamaganov and Hites, 2001; Atkinson and Arey, 2003). Moreover, the SOA particles in our flow tube experiments were freshly formed, whereas chemical aging over multiple hours may have played a role in the chamber experiments of Hoffmann et al. (1997).

Unexpectedly, the SOA yields measured under dry conditions did not exhibit a monotonous increase with decreasing temperature. Even when the statistical uncertainties of the measurement results are taken into account, the yields observed at $263 \mathrm{~K}$ were generally lower than those at $273 \mathrm{~K}$ and $278 \mathrm{~K}$ (most evident at $M_{o}>30 \mu \mathrm{g} / \mathrm{m}^{3}$; Fig. 4a) and the yields observed at $283 \mathrm{~K}$ were at $M_{o}>50 \mu \mathrm{g} / \mathrm{m}^{3}$ lower than those at both colder and warmer temperatures (Fig. 4a). This complex, non-linear behaviour will be discussed below.
Table 5. Best-fit values of the two-product model "B fits" (Sect. 2.6) to the dry data from our study and the fit parameters from Hoffmann et al. (1997) ${ }^{\mathrm{a}}$ (one-product model, Fig. 4). $K_{o m, i}=$ partitioning coefficient, $\alpha_{i}=$ stoichiometric yield, $S_{T}=$ optimised residual parameter, $n=$ number of data points (experiments).

\begin{tabular}{lrrrrrr}
\hline$T(\mathrm{~K})$ & $\begin{array}{r}K_{\text {om }, 1} \\
\left(\mathrm{~m}^{3} \mu \mathrm{g}^{-1}\right)\end{array}$ & $\begin{array}{r}K_{\text {om, }} \\
\left(\mathrm{m}^{3} \mu \mathrm{g}^{-1}\right)\end{array}$ & $\alpha_{1}$ & $\alpha_{2}$ & $S_{T}$ & $n$ \\
\hline 263 & 0.724 & 0.011 & 0.207 & 0.080 & 2.75 & 8 \\
273 & 0.319 & 0.006 & 0.284 & 0.173 & 1.73 & 5 \\
278 & 0.217 & 0.004 & 0.274 & 0.248 & 2.11 & 5 \\
283 & 0.149 & 0.003 & 0.139 & 0.184 & 9.30 & 11 \\
293 & 0.073 & 0.002 & 0.297 & 0.136 & 3.22 & 8 \\
303 & 0.038 & 0.001 & 0.264 & 0 & 4.87 & 6 \\
$292^{\mathrm{a}}$ & 0.11 & - & 0.35 & - & & \\
\hline
\end{tabular}

Figure 5 illustrates the SOA mass concentration dependence of SOA yields observed under humid conditions. It is qualitatively similar to the concentration dependence exhibited by the dry experiments and can also be fitted with the two-product model outlined in Sect. 2.5 and 2.6; the parameters of the shown fit lines are summarized in Table 6 and will be discussed below.

Compared to the dry experiments, the maximum yields decreased by $\sim 35 \%$ at $263 \mathrm{~K}$ and $273 \mathrm{~K}$ and increased by $\sim 80 \%$ and $\sim 30 \%$ at $283 \mathrm{~K}$ and $293 \mathrm{~K}$, respectively. The yields reported by Griffin et al. (1999) for $M_{o}<30 \mu \mathrm{g} \mathrm{m}^{-3}$ at $307 \mathrm{~K}-308 \mathrm{~K}$ (Fig. 5 , open triangles) are by more than a factor of 5 lower than the ones observed in our experiments at $293 \mathrm{~K}$, but their two-product model fit predicts a maximum yield comparable to our study (0.511 vs. 0.436$)$. The difference might be due to the use of an $\mathrm{OH}$ scavenger (2-butanol) in the experiments of Griffin et al. (1999).

In contrast to the irregular and weak increase of SOA yield with decreasing temperature observed under dry conditions, the humid experiments exhibited a pronounced monotonous decrease of yield with decreasing temperature as detailed below.

\subsection{Temperature dependence of SOA yield}

Figure 6 illustrates the temperature dependence of SOA yields at $M_{o}=10 \mu \mathrm{g} \mathrm{m}^{-3}$ (a) and $M_{o}=250 \mu \mathrm{g} \mathrm{m}^{-3}$ (b) as observed and modelled in our study and other investigations of SOA formation from ozonolysis of $\beta$-pinene. $M_{o}=10 \mu \mathrm{g} \mathrm{m}^{-3}$ was chosen as an exemplary atmospheric particle mass concentration level. $M_{o}=250 \mu \mathrm{g} \mathrm{m}^{-3}$ is well above typical atmospheric aerosol loadings, but it was chosen for robust comparison of measured and modelled maximum yields, because it is well in the saturation range (nearconstant maximum level of SOA yield). As illustrated in Figs. 4 and 5, the relations and conclusions obtained by comparison of effective maximum SOA yields at $250 \mu \mathrm{g} \mathrm{m}^{-3}$ are 

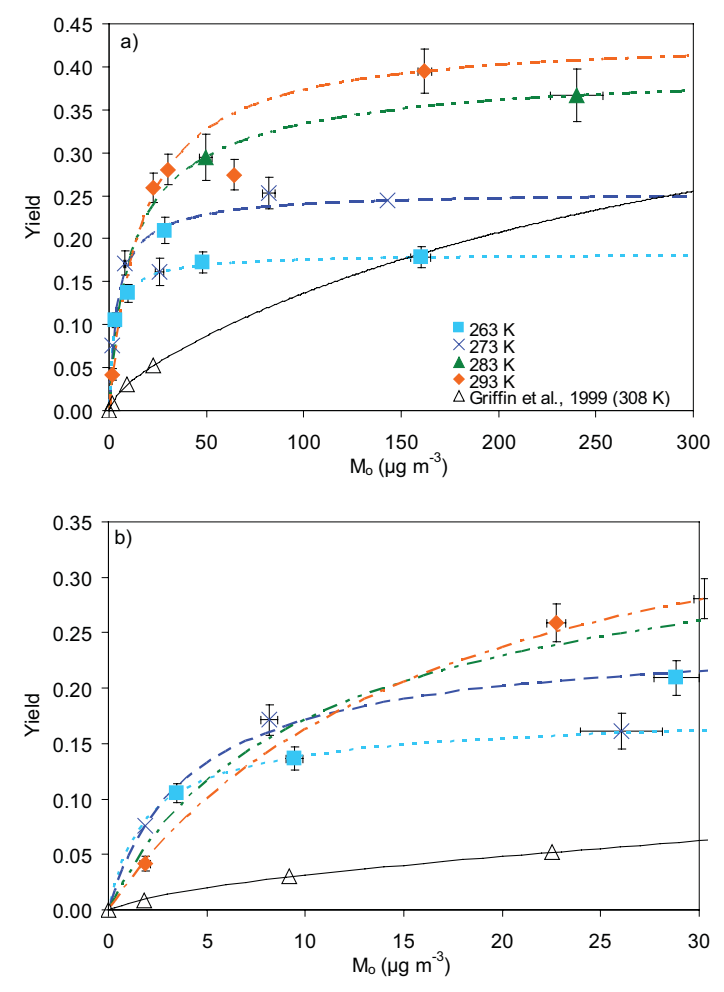

Fig. 5. Secondary organic aerosol yield $(Y)$ plotted against mass concentration of organic particulate matter $\left(M_{O}\right)$ from humid experiments performed at different temperatures (263 K-293 K): (a) all data from this study (Table 2), and Griffin et al. (1999); (b) blow-up of low $M_{o}$ range from Fig. 5a. Symbols and error bars represent the arithmetic mean and standard deviations of 9-23 replicate measurements performed in each experiment. Lines represent two-product model "B fits" (Table 6).

generally also valid for concentration levels at the lower end of the saturation range, i.e. around $100 \mu \mathrm{g} \mathrm{m}^{-3}$, which are relevant for polluted environments.

Under dry conditions the results of our and other experiments are consistent with an overall trend of increasing SOA yield with decreasing temperature, consistent with the Clausius-Clapeyron-type temperature dependence of $K_{\text {om }, i}$.

Figure 6 shows a linear fit of our data (yield vs. 1000/T). We observe a stronger temperature dependence of the yields at lower mass concentrations compared to higher mass concentrations: the slopes of the linear fits are $277 \mathrm{~K}$ for $M_{o}=10 \mu \mathrm{g} \mathrm{m}^{-3}$ and $108 \mathrm{~K}$ at $M_{o}=250 \mu \mathrm{g} \mathrm{m}^{-3}$. For comparison we also show a linear fit to the results of Jenkin (2004). It should however be noted that the reaction conditions of this study differ from those of Jenkin (2004). In Jenkin's study an $\mathrm{OH}$-scavenger and sufficient water to stabilize Criegee intermediates are included.

The measured yields of this study exhibit substantial oscillatory deviations from the predicted linear increase with $1 / T$. The largest oscillatory variations occurred between $278 \mathrm{~K}$ and $283 \mathrm{~K}$, where the SOA yield increased by a factor of $\sim 2$
Table 6. Best-fit values of the two-product model B fits (Sect. 2.6) to the humid data from our study and the fit parameters from Griffin et al. (1999)a (two-product model, Fig. 5). $K_{o m, i}=$ partitioning coefficient, $\alpha_{i}=$ stoichiometric yield, $S_{T}=$ optimised residual parameter, $n=$ number of data points (experiments).

\begin{tabular}{lrrrrrr}
\hline$T(\mathrm{~K})$ & $\begin{array}{r}K_{\text {Om, } 1} \\
\left(\mathrm{~m}^{3} \mu \mathrm{g}-{ }^{1}\right)\end{array}$ & $\begin{array}{r}K_{\text {om, } 2} \\
\left(\mathrm{~m}^{3} \mu \mathrm{g}-{ }^{1}\right)\end{array}$ & $\alpha_{1}$ & $\alpha_{2}$ & $S_{T}$ & $n$ \\
\hline 263 & 0.590 & 0.054 & 0.148 & 0.036 & 0.41 & 4 \\
273 & 0.260 & 0.028 & 0.229 & 0.026 & 4.67 & 5 \\
283 & 0.122 & 0.015 & 0.286 & 0.115 & $1.08 \mathrm{E}-06$ & 2 \\
293 & 0.060 & 0.009 & 0.435 & 0.001 & 4.79 & 5 \\
$308^{\mathrm{a}}$ & 0.195 & 0.003 & 0.026 & 0.485 & & \\
\hline
\end{tabular}

for a temperature decrease of $5 \mathrm{~K}$.

During the course of this work Pathak et al. (2008) published a study on the temperature dependence of the secondary organic mass fraction from ozonolysis of $\beta$-pinene. These experiments were carried out in a large smog chamber facility under dry conditions. At $30^{\circ} \mathrm{C}$ and aerosol levels below $20 \mu \mathrm{g} \mathrm{m}^{-3}$ our results are in reasonable agreement. At $0^{\circ} \mathrm{C}$ we observe higher yields than Pathak et al. (2008). Also Pathak et al. (2008) do not observe an oscillatory behaviour. This may be related to difference in the experimental conditions as discussed by Pathak et al. (2008).

Under humid conditions our measurement data exhibit a linear decrease with inverse temperature, which is opposite to the linear fit to the model results of Jenkin (2004). The slope of a linear fit to the data is much less steep at $M_{o}=10 \mu \mathrm{g} \mathrm{m}^{-3}(-44 \mathrm{~K})$ than at $M_{o}=250 \mu \mathrm{g} \mathrm{m}^{-3}(-620 \mathrm{~K})$. At both concentration levels the fit lines intercept the model line of Jenkin (2004) at $273 \mathrm{~K}$.

The yield reported by Lee et al. (2006) is 58\% lower than our measured yield at $250 \mu \mathrm{g} \mathrm{m}^{-3}$. $M_{o}$ was only $174 \mu \mathrm{g} \mathrm{m}^{-3}$ in the experiment of Lee et al. (2006), but according to our results this should already be in the saturation range with very similar yields as at $M_{o}=250 \mu \mathrm{g} \mathrm{m}^{-3}$.

The negative dependence on inverse temperature observed under humid conditions indicates that the SOA yield is governed much more by the temperature and humidity dependence of the involved chemical reactions than by vapour pressure temperature dependencies, which are always positive. The major differences between the results of dry and humid experiments (oscillatory positive vs. linear negative dependence on $1 / T$; up to $50 \%$ variation of $Y$ at identical $T$ ) indicate that the abundance of water vapour may actually have a stronger influence on SOA formation than temperature. Because the humid experiments in this study have been conducted at a fairly uniform level of relative humidity $(26 \%-$ $68 \%$ ), the absolute water vapour concentrations in the reactor were steeply increasing with temperature (from $0.1 \% \mathrm{v} / \mathrm{v}$ at $263 \mathrm{~K}$ to $1.6 \% \mathrm{v} / \mathrm{v}$ at $293 \mathrm{~K}$ ). Therefore the apparent positive 

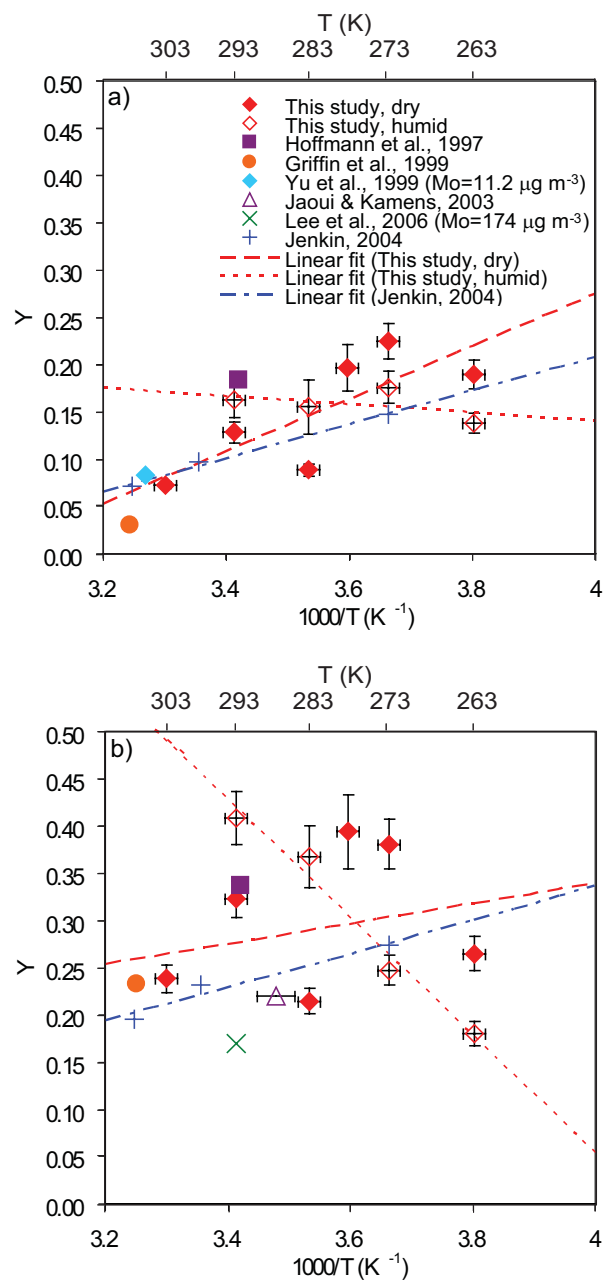

Fig. 6. Secondary organic aerosol yield $(Y)$ plotted against inverse temperature $(1000 / T):$ (a) $M_{O}=10 \mu \mathrm{g} \mathrm{m}^{-3}$; (b): $M_{O}=250 \mu \mathrm{g} \mathrm{m}^{-3}$. The symbols represent measurement or two-product model results of different studies. The error bars of the yield represent the standard deviations of 4-24 replicate measurements from our experiments with Mo close to $10 \mu \mathrm{g} \mathrm{m}^{-3}$ or $250 \mu \mathrm{g} \mathrm{m}^{-3}$ respectively. The error bars of the temperature represent the confidence interval of the thermo sensors applied in our study and the range of temperatures reported in other studies. Lines are linear fits.

temperature dependence may actually be a water vapour concentration dependence. Thus further experiments will be required for unambiguous distinction of temperature and humidity effects on the reaction pathways of SOA formation.

However, in areas with vegetation (where monoterpenes are emitted) the concentration of water vapour is mainly controlled by temperature. E.g. we experience dew-fall, when the sun sets and the air cools down. For comparison the saturation concentration of water vapour changes from $0.28 \% \mathrm{v} / \mathrm{v}$ at $263 \mathrm{~K}$ to $2.32 \% \mathrm{v} / \mathrm{v}$ at $293 \mathrm{~K}$. Thus these first experiments can give a good indication of the effect of temperature on atmospheric SOA yield under humid conditions. In any case, the strong influence of water vapour observed in our experi- ments indicates that different results from different studies of SOA formation (Fig. 6b) may well be due to changes in the involved chemical reactions caused by varying abundances of water vapour or other chemical components of the reaction mixture, such as $\mathrm{OH}$ scavengers.

Moreover, the oscillatory temperature dependence observed in our dry experiments indicates that under certain conditions large changes of SOA yield can be caused by small temperature variations.

The excited criegee radical formed upon decomposition of the primary ozonide can either undergo unimolecular decomposition or become stabilized by collision with the bath gas (M) (Winterhalter et al., 2000; Hasson et al., 2001). The relative importance of unimolecular decomposition of the excited Criegee-intermediate (Reaction R2b) and stabilization (Reaction R2a) followed by reaction with water (Reaction R3a) is most likely very dependent on temperature. The importance of unimolecular decomposition is expected to decrease with increasing temperature and this will change the product distribution and thus the yields.

For the atmospherically relevant concentration level and temperature range of $M_{o}=10 \mu \mathrm{g} \mathrm{m}^{-3}$ and $263 \mathrm{~K}-293 \mathrm{~K}$, the measurement and model results of this and earlier studies displayed in Fig. 6a indicate that the SOA yield of $\beta$-pinene ozonolysis may be well represented by an average value of 0.15 with an uncertainty estimate of \pm 0.05 . This uncertainty range comprises the results of all humid and most dry experiments of this and earlier studies in Fig. 6a as well as the model results of Jenkin (2004).

\subsection{Two-product model fit results}

Clearly, the two-product model approach is a gross simplification of the complex reaction mechanisms and multiphase processes leading to SOA formation. Nevertheless, this approach is routinely used for the modelling of SOA formation in both process studies and atmospheric models. Therefore we have fitted our measurement data with the two-product model, using two alternative fitting procedures as detailed in Sect. 2.6 ("B fit" and "free fit").

When constraining the temperature dependence of the partitioning coefficients by Eq. (11) with $B_{1}=6153 \mathrm{~K}$ and $B_{2}=5032 \mathrm{~K}$ and fitting the complete data set including all temperature levels at once ("B fit"), we obtained the results summarized in Tables 5 and 6.

Under dry conditions (Table 5), the best-fit partitioning coefficients at $303 \mathrm{~K}$ were $K_{o m}, 1,303 \mathrm{~K}=0.038 \mathrm{~m}^{3} \mu \mathrm{g}^{-1}$ and $K_{o m, 2,303 \mathrm{~K}}=0.001 \mathrm{~m}^{3} \mu \mathrm{g}^{-1}$; the $K_{o m, i}$ values at other temperatures follow the trend prescribed by Eq. (11). The stoichiometric yields exhibited temperature dependent oscillations comparable to the oscillations of the SOA yield. At all temperatures except $283 \mathrm{~K}$, the stoichiometric yield of low volatile products $\left(\alpha_{1}: 0.14-0.30\right)$ was larger than that of semi-volatile products $\left(\alpha_{2}: 0-0.25\right)$. 
Table 7. Best-fit values of the two-product model free fits (Sect. 2.6) to dry data from our study. $K_{o m, i}=$ partitioning coefficient, $\alpha_{i}=$ stoichiometric yield, $S_{T}=$ optimised residual parameter, $n=$ number of data points (experiments).

\begin{tabular}{rrrrrrr}
\hline$T(\mathrm{~K})$ & $\begin{array}{r}K_{\text {om }, 1} \\
\left(\mathrm{~m}^{3} \mu \mathrm{g}^{-1}\right)\end{array}$ & $\begin{array}{r}K_{\text {om }, 2} \\
\left(\mathrm{~m}^{3} \mu \mathrm{g}^{-1}\right)\end{array}$ & $\alpha_{1}$ & $\alpha_{2}$ & $S_{T}$ & $n$ \\
\hline 263 & 63950 & 0.037 & 0.157 & 0.119 & 2.51 & 8 \\
273 & 0.135 & 0.130 & 0.389 & 0.002 & 1.55 & 5 \\
278 & 3.017 & 0.009 & 0.193 & 0.290 & 0.53 & 5 \\
283 & 0.098 & 0.001 & 0.181 & 0.158 & 7.07 & 11 \\
293 & 0.067 & 0.001 & 0.313 & 0.119 & 3.18 & 8 \\
303 & 0.041 & 0.040 & 0.118 & 0.139 & 4.60 & 6 \\
\hline
\end{tabular}

Under humid conditions (Table 6), the best fit values of $K_{o m, 1}$ were by a factor of 0.8 lower and those of $K_{o m, 2}$ were by a factor of 5 higher than under dry conditions, indicating lower effective volatility of the lumped semi-volatile products under humid conditions. The stoichiometric yield of low-volatile products exhibited a steep increase with temperature $\left(\alpha_{1}: 0.15-0.44\right)$, corresponding to the increase of SOA yield. The stoichiometric yield of semi-volatile products exhibited no pronounced trend and was generally lower than under dry conditions $\left(\alpha_{2}: 0.001-0.1\right)$.

When fitting the data set obtained at each temperature independently ("free fit"), we obtained the results summarized in Tables 7 and 8.

Under dry conditions (Table 7), the best-fit partitioning coefficient of the lumped low-volatile products exhibited oscillatory increase with decreasing temperature ( $K_{o m, 1}: 0.04 \mathrm{~m}^{3} \mu \mathrm{g}^{-1}-64000 \mathrm{~m}^{3} \mu \mathrm{g}^{-1}$ ), whereas the partitioning coefficient of the semi-volatile products exhibited no pronounced trend and was nearly as high as that of the low-volatile species at $273 \mathrm{~K}$ and $303 \mathrm{~K}\left(K_{\text {om }, 2}\right.$ : $0.001-$ $\left.0.13 \mathrm{~m}^{3} \mu \mathrm{g}^{-1}\right)$. The stoichiometric yield of low-volatile products exhibited temperature dependent oscillations comparable to the oscillations of the SOA yield ( $\left.\alpha_{1}: 0.12-0.39\right)$, and at most temperatures except $278 \mathrm{~K}$ and $303 \mathrm{~K}$ it was larger than the stoichiometric yield of semi-volatile products $\left(\alpha_{2}: 0.002-0.29\right)$, which was inversely correlated to the oscillations of $\alpha_{1}$ and SOA yield.

Under humid conditions (Table 8), the best fit values of $K_{o m, 1}$ exhibited a pronounced monotonous increase with decreasing temperature $\left(0.06-203 \mathrm{~m}^{3} \mu \mathrm{g}^{-1}\right)$, whereas $K_{o m, 2}$ exhibited no pronounced trend and was nearly as high as that of the low-volatile species at $273 \mathrm{~K}$ and $293 \mathrm{~K}(0.06-$ $\left.0.23 \mathrm{~m}^{3} \mu \mathrm{g}^{-1}\right) . \quad \alpha_{1}$ exhibited an oscillatory increase with temperature $\left(\alpha_{1}: 0.06-0.32\right)$, and $\alpha_{2}$ exhibited inversely correlated oscillations of similar magnitude $\left(\alpha_{2}: 0.06-0.32\right)$.

The increase of $\alpha_{1}$ with increasing temperature observed under humid conditions is consistent with the increase of the yield of nucleating species inferred above from the measured particle concentrations and size distributions (Sect. 3.1). The
Table 8. Best-fit values of the two-product model free fits (Sect. 2.6) to the humid data from our study. $K_{o m, i}=$ partitioning coefficient, $\alpha_{i}=$ stoichiometric yield, $S_{T}=$ optimised residual parameter, $n=$ number of data points (experiments).

\begin{tabular}{rrrrrrr}
\hline$T(\mathrm{~K})$ & $\begin{array}{r}K_{\text {om }, 1} \\
\left(\mathrm{~m}^{3} \mu \mathrm{g}^{-1}\right)\end{array}$ & $\begin{array}{r}K_{\text {om }, 2} \\
\left(\mathrm{~m}^{3} \mu \mathrm{g}^{-1}\right)\end{array}$ & $\alpha_{1}$ & $\alpha_{2}$ & $S_{T}$ & $n$ \\
\hline 263 & 203 & 0.184 & 0.056 & 0.127 & 0.20 & 4 \\
273 & 0.233 & 0.232 & 0.196 & 0.055 & 4.59 & 5 \\
283 & 0.185 & 0.050 & 0.078 & 0.315 & $1.8 \times 10^{-08}$ & 2 \\
293 & 0.060 & 0.059 & 0.315 & 0.121 & 4.78 & 5 \\
\hline
\end{tabular}

other trends and implications of the particle concentration and size distribution measurements, however, are not directly reflected by the two-product model fit parameters. Obviously, the lumped low-volatile products cannot be readily interpreted as nucleating species that lead to new particle formation, and the lumped semi-volatile products cannot be readily interpreted as condensing species.

Overall, the differences between the results obtained with different fitting procedures and the oscillatory behaviour of the fit parameters indicate that indeed the two-product model is insufficient for a mechanistic description and reliable extrapolation of the temperature and humidity dependence of SOA formation. In view of the wide use of the two-product model and in view of the lack of readily available and efficient alternatives, however, possible mechanistic interpretations and implications of the fit parameters will be discussed below.

\subsection{Mechanistic implications of two-product model fit parameters}

The traditional two-product model exhibits a linear positive dependence of SOA yield on inverse temperature. The linear dependence is a consequence of assigning a ClausiusClapeyron-type temperature dependence to the gas-particle partitioning coefficients $K_{o m, i}$ (Sect. 2.6, Eq. 11) and assuming no temperature dependence of the stoichiometric yields $\alpha_{i}$. To reproduce the oscillations of the SOA yields under dry conditions and the negative temperature dependence under humid conditions with the two-product model, however, it is necessary to allow a temperature dependence of $\alpha_{i}$, i.e. variations of the yields of low-volatile and semi-volatile reaction products with temperature. This implies a change in product yields, i.e. the amounts of low-volatile and semi-volatile species produced, with temperature.

The formation of condensable species from volatile precursor gases involve numerous reaction steps and intermediates, and a combination of exothermal and endothermal processes may well lead to complex temperature dependencies as observed in our dry experiments. Contrary to gas-particle partitioning, which is expected to decrease the SOA yield 


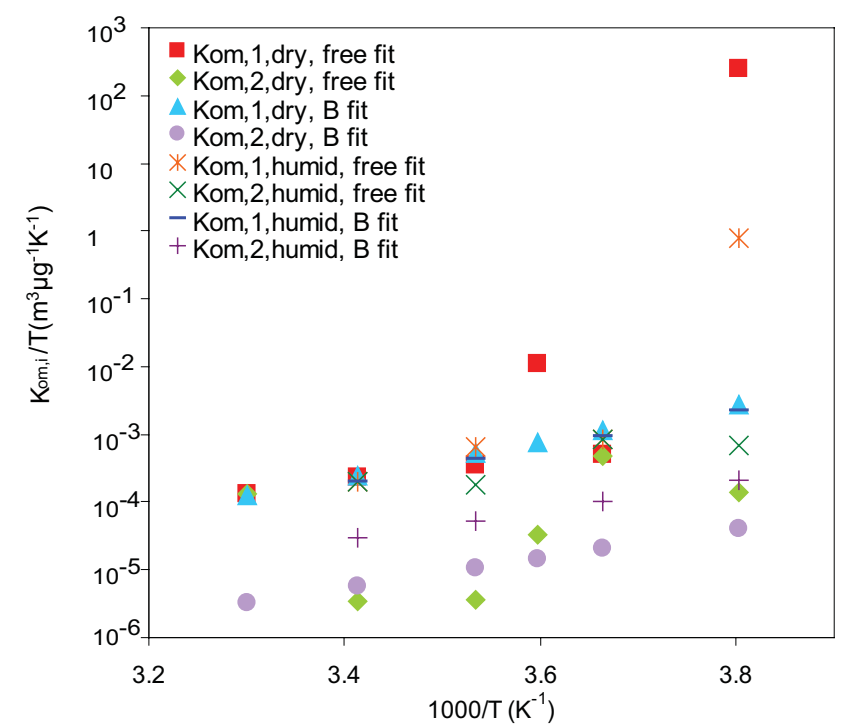

Fig. 7. Temperature-normalized partitioning coefficients $\left(K_{\text {om }, i} / T\right)$ plotted against inverse temperature.

with increasing temperature (decrease of $K_{\text {om }, i}$ with increasing $T$ ), the chemical reactions leading to second-generation products with lower volatility are likely to be accelerated at higher temperatures.

Differences in the temperature dependency of competing reaction pathways may lead to changes of the real reaction product distribution and thus to changes of the effective properties of the lumped low-volatile and semi-volatile model products (Bian and Bowman, 2005). Under these conditions, the temperature-normalized gas-particle partitioning coefficients, $K_{o m, i} / T$, are likely to exhibit deviations from the exponential dependence on inverse temperature, which is expected for constant product composition according to Eq. (11). In other words, deviations from a linear dependence of the logarithm of $K_{o m, i} / T$ on $1 / T$ indicate changes in the chemical composition of the reaction products.

In Fig. 7 the temperature-normalized partitioning coefficients, $K_{o m, i} / T$, obtained from the different fits ("B fit" and "free fit") to the dry and humid data set are plotted on a logarithmic scale against $1000 / T$ on a linear scale. The $K_{o m, i} / T$ values obtained from "B fits" exhibit a linear dependence on $1 / T$ as prescribed by Eq. (11). $K_{o m, 1} / T$ was practically the same under dry and humid conditions, whereas $K_{o m, 2} / T$ was by a factor of 5 higher under humid conditions, indicating a strong influence of humidity on the gas-particle partitioning of semi-volatile products.

Among the $K_{o m, i} / T$ values obtained by "free fits", only the $K_{o m, 2} / T$ values from the humid data set exhibit a nearlinear dependence on $1 / T$, indicating fairly constant properties and composition of semi-volatile products. The $K_{o m, 1} / T$ values and the dry $K_{o m, 2} / T$ exhibit substantial deviations from linearity, indicating changes of reaction product com- position. From $273 \mathrm{~K}$ to $263 \mathrm{~K}$ the $K_{o m, 1} / T$ exhibits a particularly pronounced increase, which is by several orders of magnitude higher than expected from the near-linear dependence observed at higher temperatures. It is tempting to speculate that this increase might be related to the freezing of water, but it is actually more pronounced under dry conditions and thus most likely due to effects of temperature on the chemical reaction mechanism and product distribution.

In any case, Fig. 7 reconfirms that the two-product model is insufficient for a mechanistic description of the temperature dependence of SOA formation. It demonstrates a need for further systematic investigations and mechanistic elucidation of the complex physico-chemical processes involved in atmospheric particle formation and gas-particle interactions (multiphase chemical reactions, mass transport, and phase transitions, Pöschl et al., 2005, 2007; Fuzzi et al., 2006).

\section{Conclusions}

Our investigations of SOA formation from the ozonolysis of $\beta$-pinene demonstrated that not only the partitioning coefficients of the reaction products but also the relative contributions of different gas-phase or multiphase reaction pathways are dependent on temperature and humidity. Under humid conditions the SOA yield was actually found to increase rather than decrease with increasing temperature, indicating that the temperature and humidity dependence of chemical reactions is more important than the temperature dependence of vapour pressures.

Further investigations are needed for mechanistic elucidation and reliable description of the complex physicochemical processes involved in SOA formation, and the influence of temperature and humidity should be considered both for gas-particle partitioning of VOC oxidation products and for the pathways and kinetics of gas phase and multiphase chemical reactions. In the atmosphere, oxidative processing and gas-particle partitioning can proceed at different temperatures, which should be taken into account in the modelling of SOA. In the tropics, for example, high temperature and humidity at the surface can promote the formation of SOA from freshly emitted BVOC, and deep convection can rapidly decrease the temperature and favour further condensation.

Acknowledgements. The authors would like to thank Gerhard Schuster for his technical expertise and support of the experimental work. Thanks to Bo Svensmark, Thorsten Hoffmann and Joachim Curtius for helpful discussions. The project was funded by the Max Planck Society. Ole John Nielsen and Merete Bilde acknowledge financial support from the Danish Natural Science Research Council.

Edited by: M. Ammann 


\section{References}

Asa-Awuku, A., Engelhart, G. J., Lee, B. H., Pandis, S. N., and Nenes, A.: Relating CCN activity, volatility, and droplet growth kinetics of -caryophyllene secondary organic aerosol, Atmos. Chem. Phys., 9, 795-812, 2009,

http://www.atmos-chem-phys.net/9/795/2009/.

Atkinson, R.: Gas-phase tropospheric chemistry of organic compounds, J. Phys. Chem. Ref. Data, 2, 1-216, 1994.

Atkinson, R. and Arey, J.: Atmospheric degradation of volatile organic compounds, Chem. Rev., 103, 4605-4638, 2003.

Atkinson, R., Aschmann, S. M., Arey, J., and Shorees, B.: Formation of $\mathrm{OH}$ radicals in the gas phase reactions of $\mathrm{O}_{3}$ with a series of terpenes, J. Geophys. Res., 97, 6065-6073, 1992.

Bahreini, R., Keywood, M. D., Ng, N. L., Varutbangkul, V., Gao, S., Flagan, R. C., Seinfeld, J. H., Worsnop, D. R., and Jimenez, J. L.: Measurements of secondary organic aerosol from oxidation of cycloalkenes, terpenes, and m-xylene using an Aerodyne aerosol mass spectrometer, Environ. Sci. Technol., 39, 5674-5688, 2005.

Bian, F. and Bowman, F. M.: Theoretical method for lumping multicomponent secondary organic aerosol mixtures, Environ. Sci. Technol., 36, 2491-2497, 2002.

Bian, F. and Bowman, F. M.: A lumping model for compositionand temperature-dependent partitioning of secondary organic aerosols, Atmos. Environ., 39, 1263-1274, 2005.

Bonn, B., Schuster, G., and Moortgat, G. K.: Influence of water vapor on the process of new particle formation during monoterpene ozonolysis, J. Phys. Chem. A, 106, 2869-2881, 2002.

Burkholder, J. B., Baynard, T., Ravishankara, A. R., and Lovejoy, E. R.: Particle nucleation following the $\mathrm{O}_{3}$ and $\mathrm{OH}$ initiated oxidation of $\alpha$-pinene and $\beta$-pinene between 278 and $320 \mathrm{~K}$, J. Geophys. Res., 112, D10216, doi:10.1029/2006JD007783, 2007.

Chen, Z. M., Wang, H. L., Zhu, L. H., Wang, C. X., Jie, C. Y., and Hua, W.: Aqueous-phase ozonolysis of methacrolein and methyl vinyl ketone: a potentially important source of atmospheric aqueous oxidants, Atmos. Chem. Phys., 8, 2255-2265, 2008, http://www.atmos-chem-phys.net/8/2255/2008/.

Chung, S. H. and Seinfeld, J. H.: Global distribution and climate forcing of carbonaceous aerosols, J. Geophys. Res., 107, 4407, doi:10.1029/2001JD001397, 2002.

Cocker, D. R., Clegg, S. L., Flagan, R. C., and Seinfeld, J. H.: The effect of water on gas-particle partitioning of secondary organic aerosol. Part I: $\alpha$-pinene/ozone system, Atmos. Environ., 35, 6049-6072, 2001.

Docherty, K. S. and Ziemann, P. J.: Effects of stabilized Criegee intermediate and $\mathrm{OH}$ radical scavengers on aerosol formation from reactions of $\beta$-pinene with $\mathrm{O}_{3}$, Aerosol Sci. Tech., 37, 877-891, 2003.

Engelhart, G. J., Asa-Awuku, A., Nenes, A., and Pandis, S. N.: $\mathrm{CCN}$ activity and droplet growth kinetics of fresh and aged monoterpene secondary organic aerosol, Atmos. Chem. Phys., 8, 3937-3949, 2008,

http://www.atmos-chem-phys.net/8/3937/2008/.

Fry, J. L., Kiendler-Scharr, A., Rollins, A. W., Wooldridge, P. J., Brown, S. S., Fuchs, H., Dubé, W., Mensah, A., dal Maso, M., Tillmann, R., Dorn, H.-P., Brauers, T., and Cohen, R. C.: Organic nitrate and secondary organic aerosol yield from $\mathrm{NO}_{3}$ oxidation of $\beta$-pinene evaluated using a gas-phase kinetics/aerosol partitioning model, Atmos. Chem. Phys., 9, 1431-1449, 2009, http://www.atmos-chem-phys.net/9/1431/2009/.
Fuzzi, S., Andreae, M. O., Huebert, B. J., Kulmala, M., Bond, T. C., Boy, M., Doherty, S. J., Guenther, A., Kanakidou, M., Kawamura, K., Kerminen, V.-M., Lohmann, U., Russell, L. M., and Pöschl, U.: Critical assessment of the current state of scientific knowledge, terminology, and research needs concerning the role of organic aerosols in the atmosphere, climate, and global change, Atmos. Chem. Phys., 6, 2017-2038, 2006,

http://www.atmos-chem-phys.net/6/2017/2006/.

Griffin, R. J., Cocker, D. R., Flagan, R. C., and Seinfeld, J. H.: Organic aerosol formation from the oxidation of biogenic hydrocarbons, J. Geophys. Res., 104, 3555-3567, 1999.

Hallquist, M., Wenger, J. C., Baltensperger, U., Rudich, Y., Simpson, D., Claeys, M., Dommen, J., Donahue, N. M., George, C., Goldstein, A. H., Hamilton, J. F., Herrmann, H., Hoffmann, T., Iinuma, Y., Jang, M., Jenkin, M., Jimenez, J. L., Kiendler-Scharr, A., Maenhaut, W., McFiggans, G., Mentel, Th. F., Monod, A., Prévôt, A. S. H., Seinfeld, J. H., Surratt, J. D., Szmigielski, R., and Wildt, J.: The formation, properties and impact of secondary organic aerosol: current and emerging issues, Atmos. Chem. Phys. Discuss., 9, 3555-3762, 2009,

http://www.atmos-chem-phys-discuss.net/9/3555/2009/.

Hartz, K. E. H., Rosenorn, T., Ferchak, S. R., Raymond, T. M., Bilde, M., Donahue, N. M., and Pandis, S. N.: Cloud condensation nuclei activation of monoterpene and sesquiterpene secondary organic aerosol, J. Geophys. Res., 110, D14208, doi:10.1029/2004JD005754, 2005.

Hasson, A. S., Ho, A. W., Kuwata, K. T., and Paulson, S. E.: Production of stabilized Criegee intermediates and peroxides in the gas phase ozonolysis of alkenes 2. Asymmetric and biogenic alkenes, J. Geophys. Res., 106, 34143-34153, 2001.

Heald, C. L., Jacob, D. J., Park, R. J., Russell, L. M., Huebert, B. J., Seinfeld, J. H., Liao, H., and Weber, R. J.: A large organic aerosol source in the free troposphere missing from current models, Geophys. Res. Lett., 32, L18809, doi:10.1029/2005GL023831, 2005.

Hoffmann, T., Odum, J., Bowman, F., Collins, D., Klockow, D., Flagan, R. C., and Seinfeld, J. H.: Formation of organic aerosols from the oxidation of biogenic hydrocarbons, J. Atmos. Chem., 26, 189-222, 1997.

Huber, P. J.: Robust Statistics, Wiley-Interscience, John Wiley \& Sons Inc., New York, 1981.

Jaoui, M. and Kamens, R. M.: Mass balance of gaseous and particulate products from $\beta$-pinene $/ \mathrm{O}_{3} /$ air in the absence of light and $\beta$-pinene $/ \mathrm{NO}_{\mathrm{x}} /$ air in the presence of natural sunlight, J. Atmos. Chem., 45, 101-141, 2003.

Jenkin, M. E.: Modelling the formation and composition of secondary organic aerosol from $\alpha$ - and $\beta$-pinene ozonolysis using MCM v3, Atmos. Chem. Phys., 4, 1741-1757, 2004, http://www.atmos-chem-phys.net/4/1741/2004/.

Jonsson, A. M., Hallquist, M., and Ljungstrom, E.: Impact of humidity on the ozone initiated oxidation of limonene, $\Delta^{3}$-carene, and $\alpha$-pinene, Environ. Sci. Technol., 40, 188-194, 2006.

Jonsson, A. M., Hallquist, M., and Ljungstrom, E.: Influence of $\mathrm{OH}$ scavenger on the water effect on secondary organic aerosol formation from ozonolysis of limonene, $\Delta^{3}$-carene and $\alpha$-pinene, Environ. Sci. Technol., 42, 5938-5944, 2008a.

Jonsson, Å. M., Hallquist, M., and Ljungström, E.: The effect of temperature and water on secondary organic aerosol formation from ozonolysis of limonene, $\Delta^{3}$-carene and a-pinene, Atmos. 
Chem. Phys., 8, 6541-6549, 2008b,

http://www.atmos-chem-phys.net/8/6541/2008/.

Kamens, R. M. and Jaoui, M.: Modeling aerosol formation from $\alpha$-pinene plus $\mathrm{NO}_{\mathrm{x}}$ in the presence of natural sunlight using gasphase kinetics and gas-particle partitioning theory, Environ. Sci. Technol., 35, 1394-1405, 2001.

Kanakidou, M., Seinfeld, J. H., Pandis, S. N., Barnes, I., Dentener, F. J., Facchini, M. C., Van Dingenen, R., Ervens, B., Nenes, A., Nielsen, C. J., Swietlicki, E., Putaud, J. P., Balkanski, Y., Fuzzi, S., Horth, J., Moortgat, G. K., Winterhalter, R., Myhre, C. E. L., Tsigaridis, K., Vignati, E., Stephanou, E. G., and Wilson, J.: Organic aerosol and global climate modelling: a review, Atmos. Chem. Phys., 5, 1053-1123, 2005, http://www.atmos-chem-phys.net/5/1053/2005/.

Keywood, M. D., Kroll, J. H., Varutbangkul, V., Bahreini, R., Flagan, R. C., and Seinfeld, J. H.: Secondary organic aerosol formation from cyclohexene ozonolysis: Effect of $\mathrm{OH}$ scavenger and the role of radical chemistry, Environ. Sci. Technol., 38, 33433350, 2004.

Khamaganov, V. G. and Hites, R. A.: Rate constants for the gasphase reactions of ozone with isoprene, $\alpha$ - and $\beta$-pinene, and limonene as a function of temperature, J. Phys. Chem. A, 105, 815-822, 2001.

Lee, A., Goldstein, A. H., Keywood, M. D., Gao, S., Varutbangkul, V., Bahreini, R., Ng, N. L., Flagan, R. C., and Seinfeld, J. H.: Gas-phase products and secondary aerosol yields from the ozonolysis of ten different terpenes, J. Geophys. Res., 111, D07302, doi:10.1029/2005JD006437, 2006.

McFiggans, G., Artaxo, P., Baltensperger, U., Coe, H., Facchini, M. C., Feingold, G., Fuzzi, S., Gysel, M., Laaksonen, A., Lohmann, U., Mentel, T. F., Murphy, D. M., O’Dowd, C. D., Snider, J. R., and Weingartner, E.: The effect of physical and chemical aerosol properties on warm cloud droplet activation, Atmos. Chem. Phys., 6, 2593-2649, 2006,

http://www.atmos-chem-phys.net/6/2593/2006/.

Nelder, J. A. and Mead, R.: A Simplex Method for Function Minimization, Comput. J., 7, 308-313, 1965.

Odum, J. R., Hoffmann, T., Bowman, F., Collins, D., Flagan, R. C., and Seinfeld, J. H.: Gas/particle partitioning and secondary organic aerosol formation, Environ. Sci. Technol., 30, 2580-2585, 1996.

Pathak, R. K., Donahue, N. M., and Pandis, S. N.: Ozonolysis of B-pinene: Temperature dependence of secondary organic aerosol mass fraction, Environ. Sci. Technol., 42, 5081-5086, 2008.

Pathak, R. K., Stanier, C. O., Donahue, N. M., and Pandis, S. N.: Ozonolysis of $\alpha$-pinene at atmospherically relevant concentrations: Temperature dependence of aerosol mass fractions (yields), J. Geophys. Res., 112, D03201, doi:10.1029/2006JD007436, 2007.

Pöschl, U.: Atmospheric aerosols: Composition, transformation, climate and health effects, Angew. Chem.-Int. Edit., 44, 7520 7540, 2005.

Pöschl, U., Rudich, Y., and Ammann, M.: Kinetic model framework for aerosol and cloud surface chemistry and gas-particle interactions: Part 1 - general equations, parameters, and terminology, Atmos. Chem. Phys. Discuss., 5, 2111-2191, 2005, http://www.atmos-chem-phys-discuss.net/5/2111/2005/.

Pöschl, U., Rudich, Y., and Ammann, M.: Kinetic model framework for aerosol and cloud surface chemistry and gas-particle interac- tions - Part 1: General equations, parameters, and terminology, Atmos. Chem. Phys., 7, 5989-6023, 2007,

http://www.atmos-chem-phys.net/7/5989/2007/.

Sheehan, P. E. and Bowman, F. M.: Estimated effects of temperature on secondary organic aerosol concentrations, Environ. Sci. Technol., 35, 2129-2135, 2001.

Shilling, J. E., Chen, Q., King, S. M., Rosenoern, T., Kroll, J. H., Worsnop, D. R., DeCarlo, P. F., Aiken, A. C., Sueper, D., Jimenez, J. L., and Martin, S. T.: Loading-dependent elemental composition of a-pinene SOA particles, Atmos. Chem. Phys., 9, 771-782, 2009,

http://www.atmos-chem-phys.net/9/771/2009/.

Svendby, T. M., Lazaridsi, M., and Tørseth, K.: Temperature dependent secondary organic aerosol formation from terpenes and aromatics, J. Atmos. Chem., 59, 25-46, 2008.

Saathoff, H., Naumann, K.-H., Möhler, O., Jonsson, Å. M., Hallquist, M., Kiendler-Scharr, A., Mentel, Th. F., Tillmann, R., and Schurath, U.: Temperature dependence of yields of secondary organic aerosols from the ozonolysis of $\alpha$-pinene and limonene, Atmos. Chem. Phys., 9, 1551-1577, 2009, http://www.atmos-chem-phys.net/9/1551/2009/.

Takekawa, H., Minoura, H., and Yamazaki, S.: Temperature dependence of secondary organic aerosol formation by photo-oxidation of hydrocarbons, Atmos. Environ., 37, 3413-3424, 2003.

Tsigaridis, K. and Kanakidou, M.: Global modelling of secondary organic aerosol in the troposphere: a sensitivity analysis, Atmos. Chem. Phys., 3, 1849-1869, 2003, http://www.atmos-chem-phys.net/3/1849/2003/.

Tunved, P., Hansson, H. C., Kerminen, V. M., Strom, J., Dal Maso, M., Lihavainen, H., Viisanen, Y., Aalto, P. P., Komppula, M., and Kulmala, M.: High natural aerosol loading over boreal forests, Science, 312, 261-263, 2006.

VanReken, T. M., Ng, N. L., Flagan, R. C., and Seinfeld, J. H.: Cloud condensation nucleus activation properties of biogenic secondary organic aerosol, J. Geophys. Res., 110, D07206, doi:10.1029/2004JD005465, 2005.

Varutbangkul, V., Brechtel, F. J., Bahreini, R., Ng, N. L., Keywood, M. D., Kroll, J. H., Flagan, R. C., Seinfeld, J. H., Lee, A., and Goldstein, A. H.: Hygroscopicity of secondary organic aerosols formed by oxidation of cycloalkenes, monoterpenes, sesquiterpenes, and related compounds, Atmos. Chem. Phys., 6, 23672388, 2006,

http://www.atmos-chem-phys.net/6/2367/2006/.

Vesna, O., Sjogren, S., Weingartner, E., Samburova, V., Kalberer, M., Gäggeler, H. W., and Ammann, M.: Changes of fatty acid aerosol hygroscopicity induced by ozonolysis under humid conditions, Atmos. Chem. Phys., 8, 4683-4690, 2008, http://www.atmos-chem-phys.net/8/4683/2008/.

Wiedinmyer, C., Guenther, A., Harley, P., Hewitt, N., Geron, C., Artaxo, P., Steinbrecher, R., and Rasmussen, R.: Global organic emissions from vegetation, in: Emissions of atmospheric trace compounds, Vol. 18, edited by: Granier, C., Artaxo, P., and Reeves, C. E., Kluwer Academic Publishers, Dordrecht, The Netherlands, 115-170, 2004.

Winterhalter, R., Neeb, P., Grossmann, D., Kolloff, A., Horie, O., and Moortgat, G.: Products and mechanism of the gas phase reaction of ozone with $\beta$-pinene, J. Atmos. Chem., 35, 165-197, 2000.

Yu, H., Kaufman, Y. J., Chin, M., Feingold, G., Remer, L. A., An- 
derson, T. L., Balkanski, Y., Bellouin, N., Boucher, O., Christopher, S., DeCola, P., Kahn, R., Koch, D., Loeb, N., Reddy, M. S., Schulz, M., Takemura, T., and Zhou, M.: A review of measurement-based assessments of the aerosol direct radiative effect and forcing, Atmos. Chem. Phys., 6, 613-666, 2006,

http://www.atmos-chem-phys.net/6/613/2006/.
Yu, J. Z., Cocker, D. R., Griffin, R. J., Flagan, R. C., and Seinfeld, J. H.: Gas-phase ozone oxidation of monoterpenes: Gaseous and particulate products, J. Atmos. Chem., 34, 207-258, 1999. 